\title{
Revision of the Neotropical trahiras of the Hoplias lacerdae species-group (Ostariophysi: Characiformes: Erythrinidae) with descriptions of two new species
}

\author{
Osvaldo T. Oyakawa ${ }^{1}$ and George M. T. Mattox ${ }^{2}$
}

Hoplias lacerdae was originally described from the rio Ribeira de Iguape, Iporanga, São Paulo State. The Hoplias lacerdae group is defined as containing generally large trahiras with the medial margins of dentaries running parallel to each other and lacking teeth on the basihyal compared to the H. malabaricus group in which the medial margins of the dentaries converge towards the mandibular symphysis and which have teeth on the basihyal. A taxonomic revision of the group based on meristic and morphometric data identified five distinct species: H. lacerdae distributed in the rio Ribeira de Iguape and rio Uruguai; $H$. intermedius from the rio São Francisco, upper rio Paraná basin, and rio Doce; $H$. brasiliensis from rivers of the Atlantic Coastal drainage from the rio Paraguaçu to the rio Jequitinhonha; $H$. australis new species, endemic to the rio Uruguai; and $H$. curupira new species present in northern South America, including the rios Negro, Trombetas, Tapajós, Xingu, Tocantins and Capim in the Amazon basin, upper rio Orinoco near the rio Casiquiare (Venezuela), and coastal rivers of Guyana and Suriname. A lectotype for Hoplias intermedius and a neotype for $H$. brasiliensis are designated.

Hoplias lacerdae foi descrita originalmente do rio Ribeira de Iguape, Iporanga, São Paulo. O grupo Hoplias lacerdae foi definido como um conjunto de espécies para abrigar as traíras geralmente de grande porte, com as margens mediais dos dentários dispostas paralelamente e sem dentes no basi-hial, em oposição às traíras do grupo Hoplias malabaricus, cujas margens mediais dos dentários convergem em direção à sínfise mandibular e possuem dentes no basi-hial. A revisão taxonômica do grupo baseada em dados merísticos e morfométricos identificou cinco espécies distintas: Hoplias lacerdae distribuída nos rios Ribeira de Iguape e Uruguai; $H$. intermedius no rio São Francisco, alto rio Paraná e rio Doce; $H$. brasiliensis nos rios costeiros da drenagem Atlântica, desde o rio Paraguaçu até o rio Jequitinhonha; $H$. australis espécie nova, endêmica ao rio Uruguai; e H. curupira espécie nova no norte da América do Sul, incluindo os rios Negro, Trombetas, Tapajós, Xingu, Tocantins e Capim na bacia Amazônica; alto rio Orinoco próximo ao rio Casiquiare (Venezuela) e rios costeiros da Guiana e Suriname. São designados um lectótipo para Hoplias intermedius e um neótipo para H. brasiliensis.

Key words: Trairão, Freshwater fish, South America, Taxonomy, Distribution patterns.

\section{Introduction}

Species of the characiform genus Hoplias are distributed throughout of the many hydrographic systems of South America and are popularly known as trahiras, trairões (= big trahiras) or lobós. They inhabit a great number of habitats, ranging from lotic environments such as small to large rivers and waterfalls, to strictly lentic waters such as lakes and reservoirs. In all habitats they are predators of other fish (Taphorn, 1992; Planquette et al., 1996). Many species are important in subsistence and commercial fisheries in various regions of Brazil and other South American countries (Goulding, 1980). Species of Hoplias can achieve considerable size, and $H$. lacerdae and $H$. aimara are among the giants of the group, reaching up to one meter in total length.

The genus can be distinguished from all other characiforms by the following derived characters: (1) contact between the vomer and parasphenoid via interdigitations; (2) a mesethmoid with an anterior projection that separates the contralateral premaxillae; (3) the contact of the anterior parts

\footnotetext{
${ }^{1}$ Museu de Zoologia da Universidade de São Paulo, Caixa Postal 42494, 04218-970 São Paulo, SP, Brazil. oyakawa@usp.br ${ }^{2}$ Departamento de Zoologia, Instituto de Biociências, Universidade de São Paulo, Caixa Postal 11461, 05422-970 São Paulo, SP, Brazil. gmattox@ib.usp.br
} 
of infraorbitals 2 and 5 with consequence exclusion of infraorbitals 3 and 4 from the orbital rim; (4) the posterior end of the maxilla with a large projection along its dorsal margin; (5) the expansion of the median region of haemal spine of the fifth vertebra; and (6) the absence of the ventral process of the third vertebra (Oyakawa, 1998).

Oyakawa (1990) used morphological characters to define three species groups in Hoplias, a practice done in other characiform genera such as Acestrorhynchus (Menezes, 1992; Toledo-Piza, 1996) and Astyanax (Garutti \& Britski, 1997). One of these groups within Hoplias was informally called the $H$. lacerdae group, which can be defined by the absence of toothbearing plates in the fleshy tissue on the dorsal surface of the basihyal and basibranchials (i.e. smooth tongue) and by the medial margins of contralateral dentaries lying almost parallel to each other, resulting in U-shaped margin in ventral view (Figs. 1a-c). The second assemblage is the H. malabaricus group, that has still not been revised, but which can be recognized by the presence of tooth-bearing plates attached to fleshy covering on dorsal surface of the basihyal and basibranchials (i.e. rough tongue) and by having the medial margins of contralateral dentaries abruptly converging towards the mandibular symphysis thereby forming a V-shaped margin in ventral view (Fig. 1d). The third is the H. macrophthalmus group, which was recently revised (Mattox et al., 2006) and determined to contain a single species, Hoplias aimara. It is defined by the absence of an accessory ectopterygoid and the presence of a dark oval spot on the opercular membrane.

Eight species are considered valid in Hoplias (Oyakawa, 2003; Mattox et al., 2006), three of which were included by
Oyakawa (1990) in the Hoplias lacerdae group: H. brasiliensis (Spix in Spix \& Agassiz, 1829), H. microcephalus (Agassiz in Spix \& Agassiz, 1829) and H. lacerdae Miranda-Ribeiro (1908). A fourth nominal species, Macrodon intermedius Günther (1864), was considered a junior-synonym of $H$. microcephalus (Oyakawa, 1990, 2003). The number of specimens of the $H$. lacerdae group in ichthyological collections has greatly increased in recent decades, reflecting an expansion of its known geographic distribution throughout South America. The purpose of this paper is to review the species of the $H$. lacerdae group, redescribe the valid species and describe two new species of the group.

\section{Material and Methods}

This study was based on meristic and morphometric data from 467 specimens. Meristic data was taken under a stereomicroscope and the morphometric data was taken pointto-point with digital calipers to $0.1 \mathrm{~mm}$. Measurements and counts were made on left side of body, whenever possible, and follow Fink \& Weitzman (1974) and Mattox et al. (2006). Unbranched and branched fin-ray counts are presented as Roman and Arabic numbers, respectively. Osteological names follow Weitzman (1962) and Roberts (1969). Descriptions of coloration were based on specimens preserved in ethanol. An identification key to species of the Hoplias lacerdae group is presented with modal meristic values presented in brackets. Institutional abbreviations follow Ferraris (2007) with addition of UFRGS, Universidade Federal do Rio Grande do Sul.
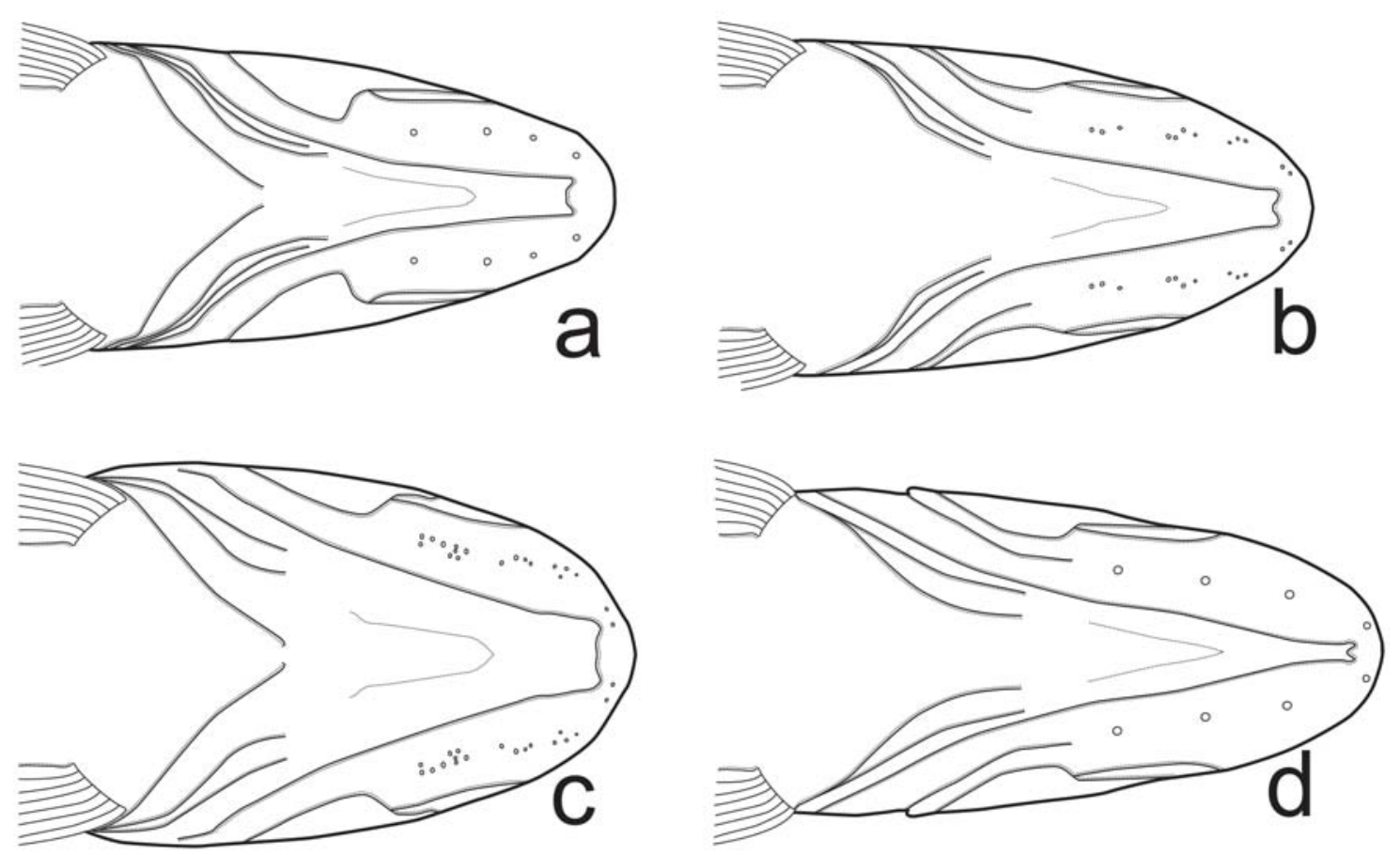

Fig. 1. Ventral view of head of (a) Hoplias curupira, MZUSP 24403, 55.5 mm SL; (b) H. curupira, MZUSP 24403, 92.2 mm SL; (c) H. curupira, MZUSP 24403, 162.2 mm SL and (d) H. malabaricus, MZUSP 90416, 101.7 mm SL. 


\section{Results}

\section{Key to species of Hoplias}

1. Medial margins of contralateral dentaries abruptly converging toward mandibular symphysis, forming a Vshaped margin in ventral view (Fig. 1d); dorsal surface of basihyal and basibranchials with tooth-bearing plates (i.e. rough tongue) Hoplias malabaricus group

1'. Medial margins of contralateral dentaries almost parallel to each other, resulting in a U-shaped margin in ventral view (Figs. 1a-c); dorsal surface of basihyal and basibranchials without tooth-bearing plates (i.e. smooth tongue)

2. Dark oval spot on opercular membrane present; accessory ectopterygoid absent Hoplias aimara

2'. Dark oval spot on opercular membrane absent; accessory ectopterygoid present ............... 3 (Hoplias lacerdae group)

3. Specimens larger than $60 \mathrm{~mm}$ SL with 4 well-defined patches of several small pores of laterosensory system along the ventral surface of dentary, specimens smaller than $60 \mathrm{~mm}$ SL only with four pores (Figs. 1a-c); lateral line scales 3439 [36] ............................................. Hoplias curupira n. sp.

3'. Specimens of any size always with 4-8 relatively large pores of laterosensory system along the ventral surface of dentary; lateral line scales 38-48

4. Laterosensory system along ventral surface of dentary with 6-8 [7] pores; lateral line scales 43-48 [46] .. Hoplias lacerdae

4'. Laterosensory system along ventral surface of dentary with 4-6 pores; lateral line scales 38-46

5. Anterior profile of head rounded in lateral view; laterosensory system along ventral surface of dentary always with 5 pores; ground coloration of head and body dark brown or dark grey .... Hoplias australis n. sp.

5'. Anterior profile of head angular in lateral view; laterosensory system along ventral surface of dentary with 4-6 pores; ground coloration of head and body dark to light brown 6 6. Lateral line scales 38-43 [41] 6'. Lateral line scales 42-46 [44] Hoplias brasiliensis Hoplias intermedius

\section{Hoplias australis, new species} Fig. 2

Holotype. BRAZIL. Santa Catarina State. Uruguay basin: MCP 40175, $220.0 \mathrm{~mm} \mathrm{SL}$, rio das Antas, rio do Ouro drainage, on Formosa do Sul-Irati road, Formosa do Sul, 263' $55^{\circ}$ "S 52 $58^{\circ} 05^{\prime \prime} \mathrm{W}$, 25 Jan 2006, C. A. Lucena, E. Pereira, V. Bertaco \& J. P. Silva.

Paratypes. ARGENTINA. Misiones. Uruguay basin: MCP 13318, 2, 41.9-42.2 mm SL, arroyo Itacaruaré, $27^{\circ} 53^{\prime} \mathrm{S} 55^{\circ} 17^{\prime} \mathrm{W}, 28$ Jun 1989, E. Lerner; MCP 13320, 1, 59.3 mm SL, arroyo Santa Maria, 2756' $55^{\circ} 27^{\prime}$ W, 28 Jun 1989, E. Lerner. BRAZIL. Rio Grande do Sul State. Uruguay basin. MCP 18561, 1, 200.6 mm SL, rio Dourado between Três Barras and Mariano Moro, Mariano Moro,
21 Sep 1995, E. Filho, V. Schulz, S. Meurer \& P. Iaczinski; MCP 19344, 1, $64.5 \mathrm{~mm}$ SL, rio Uruguay near mouths of rios Canoas and Pelotas, 2736' 22”'S 51²7’40”W, 13 Nov 1996, E. Pereira, J. Silva \& R. Reis; MZUSP 99307, 1, $225.3 \mathrm{~mm}$ SL, rio Uruguay, nearly 3 km from the Salto do Yucumã, Parque Estadual do Turvo, 2708'13”S 55³1'55”'W, 29 Oct 1991, L. Camara, L. Hanh, T. Melo \& E. Silva; MZUSP 39791, 1, 166.2 mm SL, arroio Lageado União in Linha dos Lima, Palmitinho, 22 Dec 1985, L. Malabarba, R. Reis \& S. Mallmann; UFRGS 4940, 2, 98.9-151.7 mm SL, rio Cerquinha, São José dos Ausentes, 7 Apr 2000, Equipe Ictio UFRGS; UFRGS 7064, 1, $59.1 \mathrm{~mm}$ SL, stream on the road to Pirapó, São Nicolau, 5 Mar 2005, M. Azevedo, J. Ferrer, L. Malabarba \& C. Oliveira. Santa Catarina State. Uruguay basin: MCP 12090, 1, 243.8 mm SL, rio Jacutinga, on Seára-Concórdia road, Concórdia, 22 May 1988, R. Reis, E. Pereira, P. Azevedo \& A. Bergmann; MCP 12410, 2, 217.1-234.6 mm SL, same locality, 2 Oct 1988, E. Pereira, A. Bergmann, P. Azevedo \& A. Ramires; MCP 12741, 1, 211.7 mm SL, rio Canoas, on Abdon Batista-Anita Garibaldi road, Campos Novos, 11-12 Nov 1988, C. Lucena, E. Pereira, P. Azevedo \& A. Ramires; MCP 13146, 1, 253.6 mm SL, same locality, 30-31 Mar 1989, A. Bergmann, E. Pereira, P. Azevedo, A. Ramires \& M. Vargas; MCP 18516, 2, 140.0-227.1 mm SL, rio Riacho Grande, on PiritibaBR 153 road, Concórdia, 17 Sep 1995, E. Filho, V. Schulz, S. Meurer \& P. Iaczinski; MCP 18820, 1, 199.8 mm SL; MCP 18821, 1, 198.8 mm SL, same locality, 29 Jul 1995, same collectors; MCP 18923, 2, 114.3-176.8 mm SL, same locality, 11 Jan 1996, same collectors; MCP 20847, 7, 25.2-37.2 mm SL, arroio Lageado Grande, 3 km

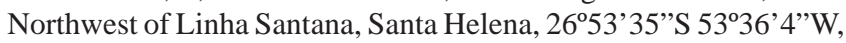
27 Jan 1998, C. Lucena, M. Lucena, E. Pereira \& J. Pezzi; MCP 20860, 1, 45.1 mm SL, rio Jundiá, on São Pedro-Tunápolis road,

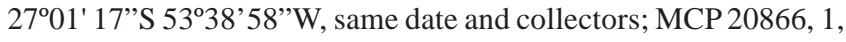
120.9 mm SL, Arroio da Taipa, on Mondaí-Itapiranga road, Mondaí $27^{\circ} 07^{\prime} 46^{\prime \prime}$ S 53⒉ $27^{\prime}$ ”, same date and collectors; MCP 40088, 1, $56.1 \mathrm{~mm}$ SL, rio Lageado Sertão, under bridge of BR 158 road,

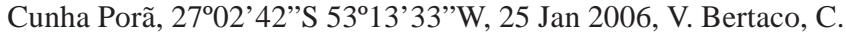
Lucena, J. Pezzi \& E. Pereira; MCP 40093, 1, 32.9 mm SL, rio Burro Branco, border between Serra Alta and Sul Brasil, 26 $41^{\circ} 12^{\prime \prime} S$ 52'49'2”'W, same date and collectors; MCP 40117, 1, 34.9 mm SL, rio Pesqueiro, on Irati-Três Amigos road, Irati, 26³9'39"S 52 $55^{\prime} 34^{\prime \prime}$ W, same date and collectors; MZUSP 99306, 1, 210.4 $\mathrm{mm} \mathrm{SL}$, rio Saudade, bridge after town of Modelo towards BR 282, Modelo, 26 $47^{\prime} 10^{\prime \prime}$ S 53 2'43”'W, same date and collectors; MCP 41287, 7, 32.9-87.5 mm SL, collected with the holotype; UFRGS 7531, 2, 246.6-252.9 mm SL, rio Jacutinga, downstream from water capture, Concórdia, 30 Oct 2004, J. Scalcon. URUGUAY. Cerro Largo. Uruguay basin: MCP 9909, 1, 352.0 mm SL; MCP 9910, 1,

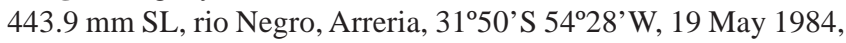
C. Lucena.

Diagnosis. The number of pores of the laterosensory canal along the ventral surface of dentary distinguished Hoplias australis from $H$. lacerdae (always 5 vs. 6-8 pores, respectively). The possession of an anterior profile of the head rounded in lateral view distinguished $H$. australis from $H$. brasiliensis and $H$. intermedius, which have the anterior profile of head angular. Hoplias australis can be further distinguished from $H$. curupira in the number of scales along lateral line (40-45 vs. 34-39 respectively).

Description. Morphometric data presented in Table 1. Body cylindrical, deeper than wide. Greatest body depth at vertical 


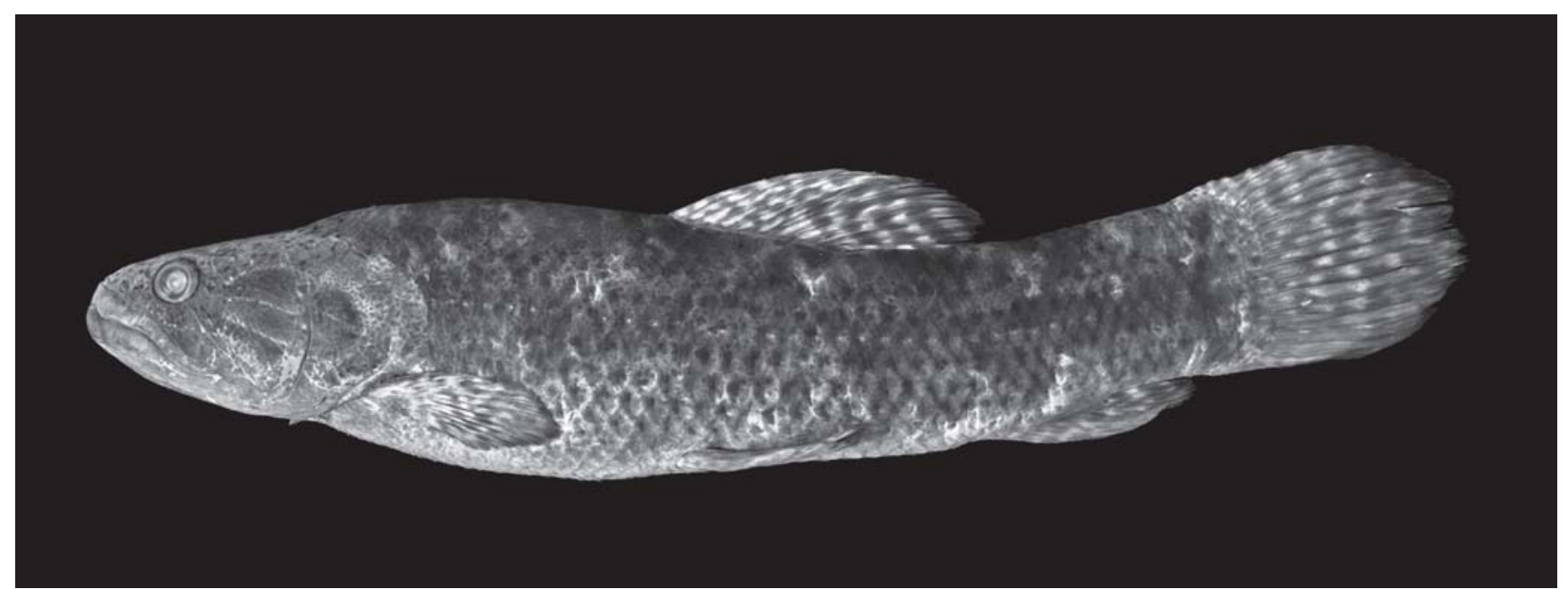

Fig. 2. Hoplias australis, holotype, MCP 40175, 220 mm SL, rio das Antas, Formosa do Sul, Santa Catarina State, Brazil.

through third scale anterior to dorsal-fin origin in specimens smaller than $90 \mathrm{~mm} \mathrm{SL}$, and through sixth scale anterior to dorsal-fin origin in larger specimens (ca. $220 \mathrm{~mm} \mathrm{SL}$ ). Anterior profile of head rounded in lateral view, but more angular in specimens smaller than $40 \mathrm{~mm}$ SL. Dorsal profile of head varying from slightly convex in specimens smaller than 40 $\mathrm{mm}$ SL to almost straight in larger individuals. Dorsal margin of orbit at horizontal through dorsal profile of head in specimens smaller than $40 \mathrm{~mm}$ SL, but not reaching dorsal profile of head in specimens larger than $90 \mathrm{~mm}$ SL. Dorsal profile of body convex from vertical through first series of scale to dorsal-fin origin; slightly straight and posteroventrally inclined along dorsal-fin base; slightly concave from vertical through base of last dorsal-fin ray to origin of dorsal most procurrent caudal-fin ray. Latter portion of profile slightly straighter in specimens smaller than $90 \mathrm{~mm}$ SL. Ventral profile of lower jaw distinctly angular in region of dentary symphysis, straight to slightly convex from vertical through anterior nostril to posterior margin of lower jaw. Medial margins of contralateral dentaries approximately parallel (Fig. 1a-c). Ventral profile of body slightly convex to pelvic-fin origin; approximately straight from latter point to anal-fin origin; straight and posterodorsally inclined along anal-fin base; slightly concave to straight from base of last anal-fin ray to anterior most ventral procurrent caudal-fin ray.

Upper jaw usually as long as lower jaw, but slightly shorter in some specimens. Posterior portion of maxilla dorsally enlarged and extending medially to anterior margins of second and third infraorbitals. Upper and lower lips fleshy with short skin projections covering canines externally. Anterior nostril tubular with anterior slit along its distal half. Anterior and posterior nostrils situated along horizontal through center of orbit, anterior nostril located at point two-thirds of orbital diameter from anterior margin of orbit. Posterior nostril situated closer to anterior nostril than to anterior margin of orbit. Eye proportionately larger in smaller specimens. Infraorbital bones well developed and horizontally elongate. Infraorbitals 3, 4,
Table 1. Morphometric data of Hoplias australis. Standard length in mm; values 1-14 are percents of standard length and values 15-22 are percents of head length. $\mathrm{n}=$ number of examined specimens.

\begin{tabular}{lccccc}
\hline & Holotype & $\mathrm{n}$ & Mean & Range & $\begin{array}{c}\text { Standard } \\
\text { deviation }\end{array}$ \\
\hline Standard length & 220.0 & 43 & - & $25.2-443.9$ & - \\
1. Body depth & 21.4 & 34 & 21.5 & $18.3-25.5$ & 2.0 \\
2. Head length & 30.0 & 36 & 31.3 & $26.2-33.7$ & 1.4 \\
3. Pectoral-fin length & 16.8 & 36 & 18.3 & $15.8-21.9$ & 1.3 \\
4. Pelvic-fin length & 16.4 & 36 & 19.3 & $16.0-22.7$ & 1.6 \\
5. Anal-fin length & 17.9 & 36 & 19.3 & $17.4-22.0$ & 1.3 \\
6. Dorsal-fin length & 26.7 & 36 & 29.1 & $25.7-33.3$ & 1.8 \\
7. Dorsal-fin base & 15.0 & 36 & 17.4 & $15.0-20.9$ & 1.2 \\
8. Anal-fin base & 9.6 & 36 & 10.0 & $8.1-12.0$ & 0.9 \\
9. Pre-pectoral distance & 26.8 & 36 & 28.9 & $24.5-32.5$ & 1.8 \\
10. Pre-pelvic distance & 51.8 & 36 & 54.5 & $50.2-58.3$ & 1.8 \\
11. Pre-dorsal distance & 49.4 & 36 & 49.9 & $45.0-53.4$ & 2.0 \\
12. Pre-anal distance & 79.3 & 36 & 80.0 & $74.6-86.0$ & 2.6 \\
13. Caudal-peduncle depth & 14.5 & 36 & 14.5 & $12.6-17.5$ & 1.1 \\
14. Caudal-peduncle length & 14.1 & 36 & 14.3 & $11.6-16.6$ & 1.1 \\
15. Head depth & 47.9 & 36 & 44.6 & $37.9-49.5$ & 3.1 \\
16. Snout length & 26.7 & 36 & 24.4 & $20.3-28.5$ & 2.1 \\
17. Snout width & 21.2 & 36 & 19.2 & $14.2-22.7$ & 2.3 \\
18. Snout depth & 23.5 & 36 & 21.3 & $16.7-27.0$ & 2.7 \\
19. Pre-nasal distance & 16.4 & 36 & 15.8 & $9.9-19.8$ & 2.0 \\
20. Orbital diameter & 18.3 & 36 & 20.6 & $13.3-29.0$ & 4.2 \\
21. Interorbital width & 24.8 & 35 & 22.1 & $14.9-26.8$ & 2.9 \\
22. Upper jaw length & 50.4 & 36 & 47.6 & $41.0-54.8$ & 3.8 \\
\hline
\end{tabular}

and ventral portion of 5 partially covering preopercle. Ventral margin of infraorbital 3 convex. Posterior margin of infraorbital 4 relatively straight and margins of infraorbitals 5 and 6 slightly convex. Small specimens (ca. $90 \mathrm{~mm} \mathrm{SL}$ ) with infraorbital 3 barely reaching orbital rim and proximal portions of infraorbitals 2 and 4 almost in contact with each other. Larger specimens (ca. $220 \mathrm{~mm} \mathrm{SL}$ ) with infraorbitals 3 and 5 completely excluded from orbital rim and infraorbital 4 barely reaching rim.

Teeth in both jaws conical or canine. Premaxillary teeth in 
single row. First premaxillary tooth large canine, second, seventh and ninth teeth medium sized. Eighth tooth canine and almost as large as anterior most premaxillary canine in large specimens (ca. $220 \mathrm{~mm} \mathrm{SL}$ ). Third to sixth premaxillary teeth small. Maxilla with single row of approximately 30 relatively small teeth. Dentary with anterior external row of teeth and posterior internal row. External series with three small anterior teeth followed by two well-developed canines, with posterior one larger. Posterior canine followed by 11 conical teeth, some half size of anterior most dentary canine. Internal series beginning proximate to small conical tooth posterior to last conical tooth of external series and composed of approximately 12 very small teeth. Accessory ectopterygoid and ectopterygoid toothed; latter with series of small conical teeth along its ventrolateral margin and many smaller viliform teeth medially along its ventral surface. Endopterygoid edentulous.

Distal margins of all fins rounded. Total dorsal-fin rays 12-14 ( $=22$; ii,10-12; mode: ii,11, $n=11$ ). Dorsal fin located at midbody, its origin at vertical through approximately second scale anterior on series along pelvic-fin origin. Length of longest dorsal-fin rays two-thirds of body depth. Anal-fin base short. Total anal-fin rays 9-11 $(n=21$; ii,7-9; mode: ii,8, $n$ $=12$ ). Tips of longest rays of depressed dorsal fin not extending beyond vertical through anal-fin origin. Total pectoral-fin rays 11-13 ( $n=22$; i,10-12; mode: $i, 11, n=9)$. Pectoral-fin origin located at vertical through posterior region of opercle. Tip of pectoral fin separated from pelvic-fin origin by four to six scales, and falling short of vertical through dorsalfin origin. Pectoral, pelvic and anal fins of similar sizes. Pelvicfin rays i,7-8 $(n=22, i, 8$ in one specimen). Pelvic-fin origin situated at midbody and approximately three scales posterior of vertical through dorsal-fin origin. Tip of pelvic fin separated from vertical through anal-fin origin by three scales in specimens smaller than $90 \mathrm{~mm}$ SL, and by up to eight scales in larger specimens (ca. $220 \mathrm{~mm} \mathrm{SL}$ ). Caudal-fin rays i,15, $\mathrm{i}(\mathrm{n}=9)$.

Well-developed, imbricated cycloid scales along body. Dorsal scales begin in series at posterior margin of parietals and overlap supraoccipital spine. Last vertical series of scales on caudal peduncle forming slightly convex arch on caudalfin base. Anterior margin of scales with small recess and posterior margin rounded. Approximately twelve radii extending from center of scale to its anterior margin and around twenty-two radii, some anastomosed, extending from center of scale to its dorsal, posterior and ventral margins. Lateral line straight and complete, extending from posteroventral margin of supracleithrum to posterior most scale in body. Lateral line with 40-45 perforated scales ( $\mathrm{n}=38$, 44 in one specimen and 45 in one specimen; mode: $41, n=12$ ) (Table 2 ). Lateral-line scales with single laterosensory canal. Longitudinal series of scales between lateral line and dorsalfin origin 4.5-5.5 ( $\mathrm{n}=21$; mode: $4.5, \mathrm{n}=15)$. Longitudinal series of scales between lateral line and pelvic-fin origin 3.55.5 ( $n=20$; mode: 4.5, $n=18)$. Longitudinal series of scales around caudal peduncle 19-20 ( $\mathrm{n}=21$; mode 20, $\mathrm{n}=20)$.

Approximately 12 gill rakers on first epibranchial, most in form of small denticulated plates. Lower branch of first branchial arch with five more elongate rakers and approximately 10 plate-like rakers $(n=9)$. Laterosensory canal along ventral surface of dentary always with five pores $(n=$ 43, Table 3).

Color in alcohol. Ground coloration of head and body dark brown or dark grey, darker dorsally and paler ventrally, latter region white or dark yellow to light brown in most specimens. Dark brown midlateral stripe along lateral line weakly evident in specimens smaller than $90 \mathrm{~mm}$ SL and almost absent in larger specimens (ca. $220 \mathrm{~mm}$ SL). Approximately seven dark blotches along lateral line with width of blotches about six longitudinal series of scales; pattern more conspicuous in specimens smaller than $90 \mathrm{~mm}$ SL. Dark coloration of body obscuring dark midlateral stripe and blotches in larger specimens. Three or four dark blotches present along dorsal surface of body. Some specimens with several small dark spots located on dorsolateral portion of body. Dorsal surface of head dark brown or grey. Numerous small black spots on dorsal surface of head of several specimens. Lips dark grey, with small vertical light bands in specimens smaller than 40 $\mathrm{mm}$ SL. Coloration of infraorbital region similar to that of dorsal surface of head. Some specimens with one or two dark stripes radiating posteriorly from eye across opercular series. Ground coloration of opercular series similar to rest of head. Opercle membrane usually as dark as opercle, but slightly lighter in some specimens.

All fins light brown or grey with dark spots on rays and interradial membrane forming pattern of irregular dark stripes. Dark and light stripes of similar width in specimens smaller than $90 \mathrm{~mm}$ SL, with dark stripes wider than light ones in larger specimens. Ventral surfaces of pectoral and pelvic fins either lighter or with pattern similar to that of dorsal surface but less conspicuous.

Table 2. Frequency distribution of total number of lateral line scales in species of the Hoplias lacerdae group.

\begin{tabular}{|c|c|c|c|c|c|c|c|c|c|c|c|c|c|c|}
\hline $\begin{array}{l}\text { Lateral Line } \\
\text { Scales }\end{array}$ & 34 & 3536 & 37 & 38 & 39 & 40 & 41 & 42 & 43 & 44 & 45 & 46 & 47 & 48 \\
\hline H. australis & & & & & & 11 & 12 & 10 & 3 & 1 & 1 & & & \\
\hline H. brasiliensis & & & & 2 & 5 & 23 & 24 & 15 & 5 & & & & & \\
\hline H. curupira & 6 & 1760 & 38 & 18 & 3 & & & & & & & & & \\
\hline H. intermedius & & & & & & & & 5 & 32 & 36 & 9 & 4 & & \\
\hline H. lacerdae & & & & & & & & & 1 & 7 & 22 & 28 & 25 & 6 \\
\hline
\end{tabular}

Table 3. Frequency distribution of total number of pores of cephalic lateral system along the ventral surface of the dentary in species of the Hoplias lacerdae group.

\begin{tabular}{lccccc}
\hline \multicolumn{1}{c}{ Pores } & 4 & 5 & 6 & 7 & 8 \\
\hline H. australis & & 43 & & & \\
H. brasiliensis & 6 & 66 & 3 & & \\
H. curupira & 151 & & & & \\
H. intermedius & 17 & 74 & 6 & & \\
H. lacerdae & & & 17 & 67 & 5 \\
\hline
\end{tabular}


Distribution. Throughout rio Uruguay basin, including its tributary rio Negro (Fig. 3).

Etymology. The name australis, an adjective, refers to the southern range of this species, one of the southern most in the genus.

Remarks. Valenciennes (1846) described Macrodon auritus based on one specimen collected in Montevideo, Uruguay, from rio Uruguay basin. It is not clear, however, from the original description whether the species belongs to the Hoplias lacerdae group or to either of the two taxa of this group documented from the rio Uruguay in this study. Unfortunately, the type specimen of $M$. auritus has not been located in MNHN, contrary to the other type specimens of the Erythrinidae described in Valenciennes (1846) [P. Pruvost, pers. comm.]. Macrodon auritus is therefore considered a nomen dubium (ICZN, 1999).
Two species of Hoplias lacerdae group, H. australis and $H$. lacerdae, occur in sympatry and syntopy in the rio Uruguay basin, and were collected together at some localities. Hoplias lacerdae also occurs in the rio Ribeira de Iguape (see below), and $H$. australis is, thus, the only Hoplias species apparently endemic to the rio Uruguay basin. Judging from the amount of material in museum collections, $H$. australis is much less common in the rio Uruguay than H. lacerdae.

\section{Hoplias brasiliensis (Spix, 1829) \\ Fig. 4}

Erythrinus brasiliensis Spix in Spix \& Agassiz, 1829: 45, pl. 20 [original description, type locality: Paraguaçú, Bahia State, Brazil]. -Günther, 1864: 281 [species list as synonym of Macrodon trahira]. -Lütken, 2001: 78 [footnote,

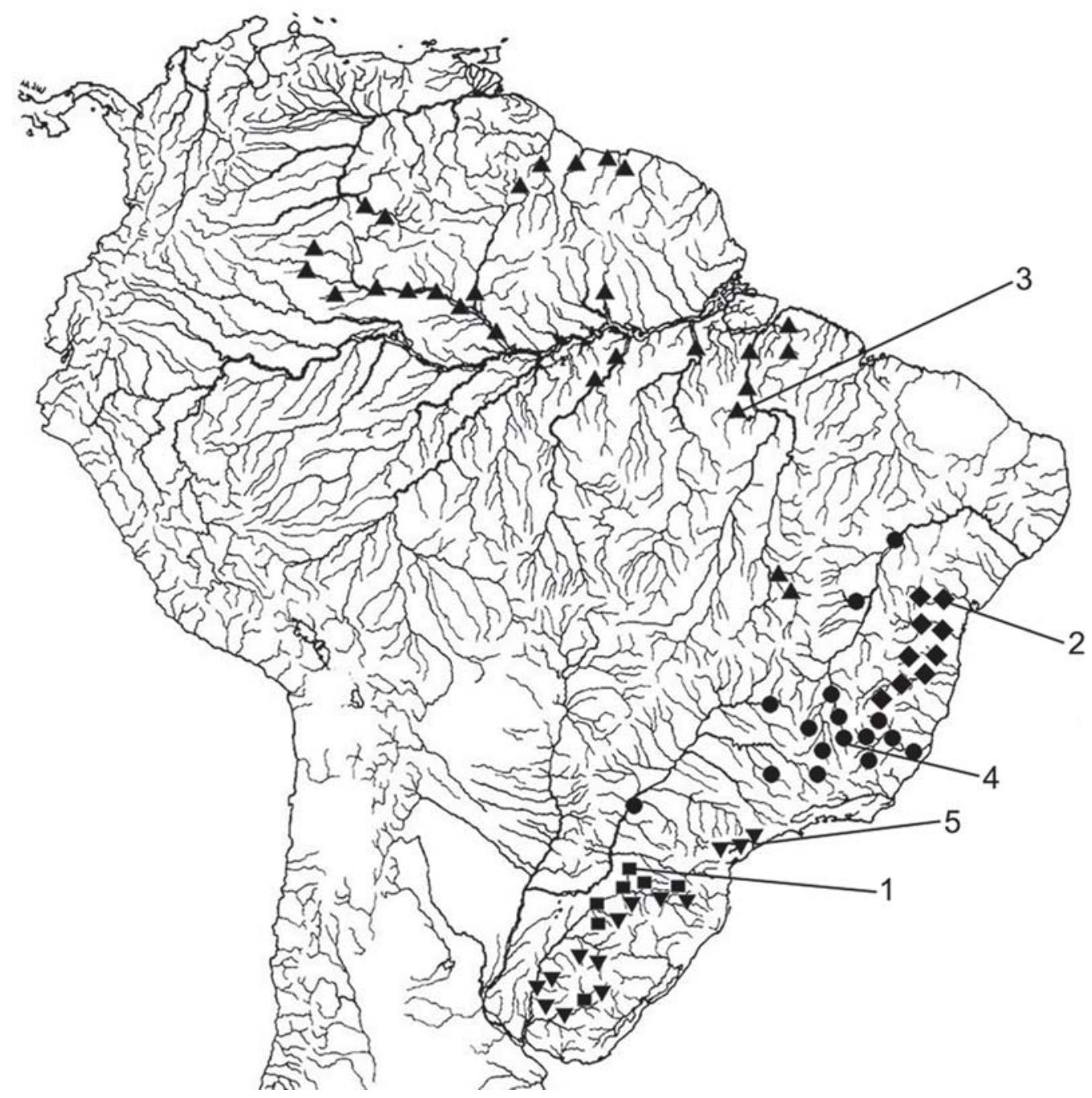

Fig. 3. Map of South America showing geographic distribution of species of the Hoplias lacerdae group based on material examined in this study. Some symbols may represent more than one lot. Numbers indicate type localities of (1) Hoplias australis (squares); (2) H. brasiliensis (losanges); (3) H. curupira (triangles); (4) H. intermedius (dots); and (5) H. lacerdae (inverted triangles). 
synonym of Macrodon trahira]. -Eigenmann \& Eigenmann, 1889: 103 [species list as synonym of Macrodon malabaricus]. -Eigenmann, 1910: 448 [species list as synonym of Hoplias malabaricus]. -Eigenmann, 1912: 416 [species list as synonym of Hoplias malabaricus]. -Fowler, 1950: 364 [species list as synonym of Hoplias malabaricus malabaricus]. -Godoy, 1975: 405 [as synonym of Hoplias malabaricus malabaricus].

Macrodon brasiliensis: -Müller, 1842: 309 [species list]. Müller, 1843: 316 [species list]. -Müller \& Troschel, 1844: 82 [species list]. -Müller \& Troschel, 1845: 6 [species list]. -Godoy, 1975: 405 [as synonym of Hoplias malabaricus malabaricus].

Hoplias brasiliensis: -Oyakawa, 2003: 239 [species list, distribution]. -Oyakawa \& Netto-Ferreira, 2007: 63 [species list, distribution]. -Menezes et al., 2007: 152 [type-locality, distribution].

Neotype. BRAZIL. Bahia State. MZUSP 45483, 1, 162.9 mm SL, rio Paraguaçú near Iaçú, 25 Jul 1988, R. Castro, S. Jewett \& H. Santos. [designated herein].

Material examined. BRAZIL. Bahia State. Paraguaçú basin: MZUSP 40171, 10, 39.3-122.8 mm SL; MZUSP 40172, 7, 41.394.9 mm SL, rio Paraguaçú near Iaçú; MZUSP 47939, 11, 23.7-66.2 mm SL; MZUSP 49234, 12, 23.1-65.1 mm SL, rio do Una, rio Paraguaçú drainage, Itaetê; MZUSP 40173, 1, 114.5 mm SL, lagoa Charca Natividade, floodplain of rio Paraguaçú, Iaçú; MZUSP 86123, 1, 112.5 mm SL, rio do Una, Rumo village, Itaetê; MZUSP 87684, 2, 83.9-132.2 mm SL, rio do Una, Fazenda Nova Iguaçú, Itaetê. Bahia, rio de Contas basin: MZUSP 40174, 1, 82.7 mm SL, rio Gongoji, tributary to rio de Contas, Fazenda Itamarati, $5 \mathrm{~km}$ from Dário Meira; MZUSP 41500, 2, 32.1-35.1 mm SL; MZUSP 39797, 7, 19.2-54.0 mm SL, rio de Contas, Ipiaú. Bahia. Pardo basin: MZUSP 40170, 2, 193.9-205.7 mm SL, rio Pardo, Fazenda Hermógenes, $5 \mathrm{~km}$ upstream from ferry-crossing, Itapetininga. Minas Gerais State. Jequitinhonha basin: MZUSP 40269, 7, 95.5273.4 mm SL, rio Jequitinhonha near Araçuaí, Vila Itira; MZUSP
40270, 7, 38.7-137.0 mm SL, rio Jequitinhonha, Ilha Almenara, Curiango; MZUSP 74032, 3, 27.8-39.4 mm SL, marginal lagoon of rio Jequitinhonha, km 205 of Salto da Divisa-Jacinto road.

Diagnosis. The number of pores of the laterosensory canal along the ventral surface of the dentary distinguished Hoplias brasiliensis from $H$. lacerdae (4-6 vs. 6-8 respectively). It can be distinguished from $H$. intermedius by the number of the scales along the lateral line (38-43 vs. 42-46 respectively). The anterior profile of head that is angular in lateral view distinguished $H$. brasiliensis from $H$. australis, $H$. curupira and $H$. lacerdae, which have the anterior profile of head rounded. It can be further distinguished from $H$. curupira by having light brown ground coloration of the head and body.

Description. Morphometric data presented in Table 4. Body cylindrical, deeper than wide. Greatest body depth at vertical through fifth scale anterior to dorsal-fin origin in specimens smaller than $35 \mathrm{~mm}$ SL, closer to dorsal-fin origin in larger specimens. Anterior profile of head angular in lateral view, more rounded in specimens smaller than $100 \mathrm{~mm}$ SL. Dorsal profile of head varying from slightly convex in specimens smaller than $100 \mathrm{~mm}$ SL to almost straight in specimens larger than $130 \mathrm{~mm}$ SL. Dorsal margin of orbit located at horizontal to through dorsal profile of head in specimens smaller than 100 mm SL but not reaching dorsal profile of head in specimens larger than $130 \mathrm{~mm}$ SL. Dorsal profile of body slightly convex from vertical through first series of scale of body to dorsal-fin origin in specimens smaller than $130 \mathrm{~mm}$ SL and almost straight in larger specimens (ca. $280 \mathrm{~mm} \mathrm{SL);} \mathrm{straight} \mathrm{and}$ posteroventrally inclined along dorsal-fin base; straight and less inclined to slightly concave from vertical through base of last dorsal-fin ray to origin of dorsal most procurrent caudalfin ray. Latter portion of profile slightly more concave in specimens smaller than $130 \mathrm{~mm}$ SL. Ventral profile of lower jaw distinctly angular in region of dentary symphysis, straight

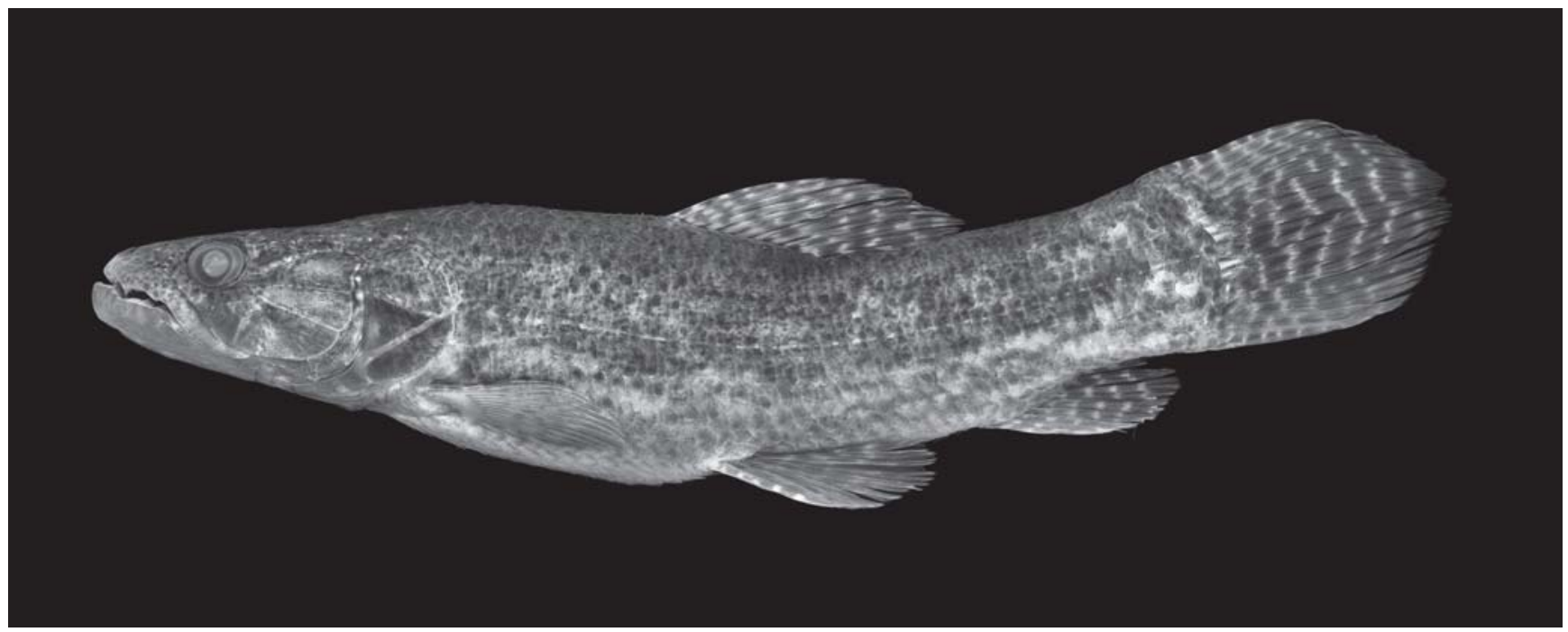

Fig. 4. Hoplias brasiliensis, neotype, MZUSP 45483, 162.9 mm SL, rio Paraguaçú near Iaçú, Bahia State, Brazil. 
Table 4. Morphometric data of Hoplias brasiliensis. Standard length in mm; values 1-14 are percents of standard length and values 15-22 are percents of head length. $\mathrm{n}=$ number of examined specimens.

\begin{tabular}{lccccc}
\hline & Neotype & $\mathrm{n}$ & Mean & Range & $\begin{array}{c}\text { Standard } \\
\text { deviation }\end{array}$ \\
\hline Standard length & 162.9 & 75 & - & $19.2-273.8$ & - \\
1. Body depth & 23.8 & 75 & 22.0 & $17.7-25.9$ & 1.8 \\
2. Head length & 35.2 & 75 & 33.7 & $30.9-37.4$ & 1.2 \\
3. Pectoral-fin length & 20.5 & 72 & 19.7 & $14.5-22.8$ & 1.8 \\
4. Pelvic-fin length & 21.2 & 75 & 20.4 & $17.4-23.3$ & 1.2 \\
5. Anal-fin length & 19.2 & 75 & 19.5 & $16.6-33.1$ & 2.0 \\
6. Dorsal-fin length & 28.1 & 75 & 29.8 & $25.6-34.8$ & 1.8 \\
7. Dorsal-fin base & 14.8 & 75 & 16.8 & $14.1-21.8$ & 1.4 \\
8. Anal-fin base & 10.3 & 75 & 9.7 & $7.7-20.1$ & 1.5 \\
9. Pre-pectoral distance & 32.5 & 75 & 31.6 & $28.4-35.6$ & 1.6 \\
10. Pre-pelvic distance & 58.7 & 75 & 56.2 & $53.9-58.7$ & 1.1 \\
11. Pre-dorsal distance & 52.9 & 75 & 52.4 & $49.0-55.9$ & 1.4 \\
12. Pre-anal distance & 83.6 & 75 & 80.3 & $76.4-85.4$ & 1.6 \\
13. Caudal-peduncle depth & 14.3 & 75 & 13.9 & $12.3-15.6$ & 0.7 \\
14. Caudal-peduncle length & 13.8 & 75 & 13.5 & $10.2-15.4$ & 1.1 \\
15. Head depth & 41.4 & 75 & 40.1 & $34.2-45.4$ & 2.2 \\
16. Snout length & 26.1 & 75 & 23.7 & $18.8-28.4$ & 1.9 \\
17. Snout width & 19.7 & 75 & 17.8 & $12.6-21.9$ & 1.7 \\
18. Snout depth & 21.4 & 75 & 17.9 & $9.8-22.4$ & 2.4 \\
19. Pre-nasal distance & 16.5 & 74 & 14.5 & $9.4-18.1$ & 1.8 \\
20. Orbital diameter & 18.4 & 75 & 24.5 & $16.2-33.3$ & 3.8 \\
21. Interorbital width & 22.1 & 75 & 19.1 & $16.4-26.0$ & 1.8 \\
22. Upper jaw length & 48.7 & 75 & 46.2 & $36.6-52.5$ & 3.0 \\
\hline
\end{tabular}

and slightly inclined from vertical through anterior nostril to posterior margin of lower jaw. Medial margins of contralateral dentaries running in parallel (Fig. 1a-c). Ventral profile of body slightly convex to pelvic-fin origin; approximately straight from latter point to anal-fin origin; straight and posterodorsally inclined along anal-fin base; slightly concave from last analfin ray to anterior most ventral procurrent caudal-fin ray.

Upper jaw slightly shorter than lower jaw. Posterior portion of maxilla dorsally enlarged and extending medial of anterior margins of second and third infraorbitals. Upper and lower lips fleshy with short projections of skin covering canines externally. Anterior nostril tubular with anterior slit along its distal half. Anterior and posterior nostrils situated along horizontal through center of orbit, anterior nostril two-thirds of orbital diameter from anterior margin of orbit; posterior nostril midway between anterior margin of orbit and anterior nostril. Eye proportionately larger in smaller specimens. Infraorbital bones well developed and horizontally elongate. Infraorbitals 3, 4, and ventral portion of 5 partially covering preopercle. Ventral margin of infraorbital 3 and posterior margins of infraorbitals 4, 5, and 6 convex. Small specimens (ca. $35 \mathrm{~mm} \mathrm{SL}$ ) with infraorbital 3 excluded from orbital rim and proximal ends of infraorbitals 2 and 4 in contact. Larger specimens ( $c a .130 \mathrm{~mm} \mathrm{SL}$ ) with infraorbital 4 barely reaching orbital rim and infraorbital 5 gradually separated from rim. Proximal ends of infraorbitals 2 and 6 almost meeting in some of largest specimens (ca. $280 \mathrm{~mm} \mathrm{SL}$ ).

Teeth in both jaws conical or canine. Premaxillary teeth in single row. First premaxillary tooth large canine, second, sixth and eighth teeth medium sized. Seventh tooth canine almost as large as anterior most premaxillary canine. Third to fifth and ninth premaxillary teeth small. Maxilla with single row of approximately 32 relatively small teeth, except for very welldeveloped canine-like fourth tooth. Dentary with anterior external row of teeth and posterior internal row. External series with four anterior small teeth, followed by two well-developed canines, with posterior canine larger than anterior canine and followed by 8 conical teeth slightly smaller than anterior most dentary canine. Internal series beginning at length of nearly one conical tooth posterior to last conical tooth of external row and formed of approximately 11 very small teeth. Accessory ectopterygoid and ectopterygoid toothed; latter with series of small conical teeth along its ventrolateral margin and with many smaller viliform teeth on its ventromedial surface. Endopterygoid edentulous.

Distal margins of all fins rounded. Total dorsal-fin rays 12-14 (n = 75; ii,11; ii,10 in two specimens and ii,12 in five specimens). Dorsal fin located at midbody, its origin at vertical through approximately third scale anterior on series along pelvic-fin origin. Length of longest dorsal-fin rays two-thirds of body depth. Anal-fin base short. Total anal-fin rays 9-10 (n $=75$; ii,8, ii,7 in five specimens). Tip of depressed dorsal fin reaching vertical through anal-fin origin. Specimens smaller than $35 \mathrm{~mm}$ SL with tip of anal fin (third to sixth branched rays) reaching origin of anterior most ventral procurrent ray of caudal fin. Total pectoral-fin rays 12-14 ( $=70$; i,11-13; mode: i,12, $n=40$ ). Pectoral-fin origin located at vertical through central portion of opercle. Tip of pectoral fin separated from pelvic-fin origin by four to six scales. Pectoral and pelvic fins of similar size and slightly larger than anal fin. Pelvic-fin rays i,7 ( $\mathrm{n}=75$, i,5 in one specimen). Pelvic-fin origin situated at midbody approximately three scales posterior to vertical through dorsal-fin origin. Tips of pelvic fin separated from vertical through anal-fin origin by four or five scales. Caudal-fin rays $\mathrm{i}, 15, \mathrm{i}(\mathrm{n}=71,14$ branched rays in one specimen).

Well developed cycloid scales imbricated along body. Dorsal scales begin in series at posterior margin of parietals and overlap supraoccipital spine. Last vertical series of scales on caudal peduncle forms slightly convex arch on caudal-fin. Anterior margin of scales with small recess and posterior margin rounded. Approximately twelve radii extending from center of scale to its anterior margin and around twenty-five radii, some anastomosed, extending from center of scale to dorsal, posterior and ventral margins. Lateral line straight and complete, extending from posteroventral margin of supracleithrum to posterior most scale in body. Lateral line with 38-43 perforated scales ( $\mathrm{n}=74,38$ in two specimens; mode: $41, \mathrm{n}=24$ ) (Table 2). Lateral-line scales with single laterosensory canal. Longitudinal series of scales between lateral line and dorsal-fin origin $5.5(\mathrm{n}=75)$. Longitudinal series of scales between lateral line and pelvic-fin origin 4.5$5.5(n=75$; mode: $5.5, n=72$ ). Longitudinal series of scales around caudal peduncle $18-20(\mathrm{n}=73$; 18 scales in two specimens). 
Approximately eight gill rakers on first epibranchial, most in form of small denticulated plates. Lower branch of first branchial arch with five or six more elongate rakers and approximately 10 plate-like rakers $(n=8)$. Laterosensory canal along ventral surface of dentary with 4-6 pores $(n=75$; mode: $5, \mathrm{n}=66$ ) (Table 3).

Color in alcohol. Ground coloration of head and body dark to light brown, darker dorsally and paler ventrally. Single dark midlateral stripe along lateral line separating dark dorsal from lighter ventral region. Stripe more evident in specimens smaller than $130 \mathrm{~mm}$ SL, the only color feature in very small specimens (ca. $35 \mathrm{~mm} \mathrm{SL}$ ). Specimens larger than $100 \mathrm{~mm}$ SL with five or six dark blotches along dark longitudinal stripe, some of them connected with contralateral blotch by dark dorsal saddle. Dorsal surface of head dark brown. Lips with alternating dark and light, thin, vertical bands. Ventral surface of head white. Coloration of infraorbital region and dorsal surface of head similar. Many specimens with two dark stripes radiating posteriorly from eye across opercular series and with third dark stripe extending posteroventrally from eye along infraorbital 2. Ground coloration of opercular series dark brown. Opercular membrane usually lighter than opercle.

All fins light brown and lighter than body, with dark spots on rays and interradial membrane forming pattern of irregular dark stripes. Stripes of anal and caudal fins wider than those of dorsal fin with stripes more irregular in anal fin. Pectoral, pelvic, and anal fins with paler pattern than dorsal and caudal fins. Ventral surfaces of pectoral and pelvic fins either lighter than, or with same pattern, as dorsal surface of fin, but with pattern less conspicuous.

Distribution. Coastal rivers of northeastern Brazil, from the rio Paraguaçú in Bahia State to rio Jequitinhonha in Minas Gerais and Espírito Santo States, including rio de Contas and rio Pardo (Fig. 3).

Remarks. Specimens used by Spix \& Agassiz (1829) to describe Erythrinus brasiliensis and deposited in the Zoologische Staatssammlung München, were destroyed during a bombing raid in the Second World War (Terofal, 1983; Kottelat, 1988; Neumann, 2006). The holotype of Erythrinus brasiliensis is not among the specimens studied by Spix \& Agassiz in the Musée d'Histoire Naturelle, Neuchâtel, and is therefore judge to be missing. Its original description, however, mentioned the "tongue [...] edentate" and "branches of the lower jaw rather distant from each other and somewhat spread out below [...] parallel to one another" [our translation]. These observations confirm that $E$. brasiliensis is a member of the Hoplias lacerdae group. Data presented in this study match the remaining information in the original description. Since the holotype of E. brasiliensis is lost, and in order to clarify the taxonomic status of this nominal species, a neotype is designated in accordance to Article 75 of the International Code of Zoological Nomenclature (ICZN, 1999). The taxon is redescribed herein, with characters diagnosing it from other members of the genus.

Castelnau (1855) identified some specimens collected in the rio Carandaí, a tributary of rio das Mortes, Minas Gerais State, as Erythrinus brasiliensis and stated that the specimens attained $50 \mathrm{~cm} \mathrm{SL}$. According to the results of the present study, Hoplias brasiliensis attains only $30 \mathrm{~cm} \mathrm{SL}$, being the smallest among species of the H. lacerdae group. The river mentioned by Castelnau (1855) belongs to the rio Grande basin, upper rio Paraná, and the available name for the specimens cited by that author is $H$. intermedius, a form that can reach $50 \mathrm{~cm}$ SL.

Rivers in which Hoplias brasiliensis occurs drain the Atlantic coast of Brazil, from the rio Paraguaçu to the rio Jequitinhonha. The region of occurrence of this species lies south and east of the rio São Francisco and north of the rio Doce. Pellegrino et al. (2005) proposed that the origin of rio Doce, together with the formation of current rio São Francisco, were responsible for isolating this region. The area from southern coastal Bahia to the northern portion of Espírito Santo is inhabited by many endemic taxa, and is considered a "hotspot" of biodiversity (Bizerril, 1994; Chomitz et al., 2005; Galindo-Leal \& Câmara, 2005; Rocha et al., 2005). Examples of endemic fishes from that region can be found in the studies of Menezes (1988), Weitzman et al. (1988), Zanata \& Akama (2004), Britto et al. (2005), Garavello (2005), Lucinda (2005), Bertaco \& Lucena (2006), Sarmento-Soares et al. (2006a, b), Zanata \& Camelier (2009), among others. Many other organisms are also known to be endemic to this region, including plants (Harley, 1988; Soderstrom et al., 1988; Thomas et al., 1998), amphibians (Cruz \& Pimenta, 2004), lizards (Rodrigues et al., 2002; Pellegrino et al., 2005), birds (Silva et al., 2004; Silveira et al., 2005), and mammals (Emmons \& Vucetich, 1998; Ventura et al., 2004).

\section{Hoplias curupira, new species Fig. 5}

Hoplias aff. lacerdae: -Lima et al., 2005: 155 [species list, occurrence in the rio Tiquié, tributary of upper rio Negro, biological, ecological and ethnoichthyological notes].

Holotype. BRAZIL. Pará State. Tocantins basin: MZUSP 45582, 157.9 mm SL, rio Itacaiúnas, Caldeirão, Serra dos Carajás, 0545’S 50³0’W, Mar 1983, M. Goulding.

Paratypes. BRAZIL. Pará State. Tocantins basin: INPA 26893, 3, 156.4-219.3 mm SL rio Itacaiúnas, Caldeirão, 15 Oct 1983, M. Goulding; MCP 41288, 4, 128.2-211.2 mm SL, same locality, 14 Oct 1983; MNRJ 30395, 4, 136.1-168.7 mm SL, same locality and date; MZUSP 33481, 1, $250.0 \mathrm{~mm}$ SL, same locality and collector, Jun-Jul 1983; MZUSP 22283, 4, 94.9-225.7 mm SL, Igarapé Pacuí on km 97 of Belém-Brasília road, 15 Aug - 20 Oct 1959, Expedição Departamento de Zoologia.

Material examined. BRAZIL. Amazonas State. Negro basin: MZUSP 34011, 2, 216.4-220.8 mm SL; MZUSP 34013, 1, 271.5 
mm SL; MZUSP 34014, 2, 207.9-272.4 mm SL; MZUSP 34017, 2, 254.0-275.8 mm SL; MZUSP 34018, 9, 232.6-298.8 mm SL; MZUSP 34019, 2, 226.1-245.0 mm SL, Anavilhanas, rio Negro; MZUSP 32355, 12, 66.6-105.8 mm SL, lake on island of rio Negro, Barcelos; MZUSP 32361, 3, 58.6-68.0 mm SL, lake on Ilha de Tamaraquaré, rio Negro; MZUSP 32364, 1, 101.63 mm SL, Cachoeira de São Gabriel, rio Negro; MZUSP 32365, 1, 129.3 mm SL, rio Negro upstream of Barcelos; MZUSP 32366, 4, 61.3-81.6 mm SL, rio Negro downstream of rio Daraá; MZUSP 32371, 2, 89.4-133.9 mm SL; MZUSP 43682, 1, 138.5 mm SL, rio Negro, Cururu; MZUSP 34010, 1, 231.2 mm SL, Ilha Buiú-Açú, rio Negro; MZUSP 34015, 2, 260.0-295.9 mm SL, rio Marauiá near the mouth; MZUSP 34020, 1, 191.8 mm SL, rio Negro right below rio Daraá; MZUSP 34012, 3, 146.4-213.1, rio Negro, Barcelos; MZUSP 62078, 1, 52.9 mm SL, rio Negro; MZUSP 81351, 1, 232.1 mm SL, Igarapé Umari Norte at rio Tiquié, São Pedro community; MZUSP 81520, 3, 188.6-206.7 mm SL, rio Tiquié, Caruru community; MZUSP 92300, 1, 90.1 mm SL, rio Tiquié between communities São José do Meio and Floresta; MZUSP 92925, 1, 14.8 mm SL, igarapé Castanha, tributary of rio Tiquié, Sítio Belém, below community Santa Rosa; MZUSP 93097, 1, 146.8 mm SL, igarapé Castanha, tributary of rio Tiquié, surroundings of Sítio São Pedro; MZUSP 91580, 2, 85.3-91.7 mm SL, rio Uaupés. Pará State. Trombetas basin: MZUSP 23664, 23, 18.7-206.1 mm SL, igarapé Jaramacuru, tributary of rio Cuminá, rio Trombetas. Pará State. Tocantins basin: MZUSP 23933, 1, 108.5 mm SL, igarapé Canteiro near Vila Santana, rio Capim; MZUSP 24117, 1, 97.5 mm SL, lagoon near Jatobal, rio Tocantins; MZUSP 24203, 10, 57.3-164.4 mm SL, igarapé $11 \mathrm{~km} 11$ of Tucuruí-Mato Grosso road; MZUSP 32333, 24, 39.0-123.1 mm SL; MZUSP 33479, 9, 231.2-312.4 mm SL; MZUSP 33480, 1, 229.3 mm SL; MZUSP 33482, 1, 232.0 mm SL; MZUSP 33484, 4, 186.9-255.4 mm SL; MZUSP 33487, 4, 136.7185.0 mm SL; MZUSP 50359, 4, 166.0-245.0 mm SL, rio Itacaiúnas, Caldeirão, Serra dos Carajás;MZUSP 79078, rio Itacaiúnas, Marabá. MZUSP 33490, 8, 122.5-219.6 mm SL; MZUSP 33492, 1, 198.9 mm SL. Pará State. Xingu basin: MZUSP 38853, 9, 40.9-67.2 mm SL, rio Xingu, Belo Monte; MZUSP 32344, 1, 99.6 mm SL, rio Xingu near waterfall in Belo Monte; MZUSP 36019, 1, 241.7 mm SL, rio Fresco at Aldeia Gorotire, São Félix do Xingu. Pará State. Tapajós basin: MZUSP 25304, 3, 187.8-194.1 mm SL, rio Tapajós downstream from the Porto Flexal; MZUSP 25464, 1, $158.6 \mathrm{~mm}$ SL, rio Tapajós in Porto Flexal; MZUSP 32346, 5, 47.1-109.7 mm
SL, rio Tapajós, igarapé on Jacareaganga-Itaituba road. Goiás State. Tocantins basin: MZUSP 40722, 2, 38.3-56.2 mm SL, rio Bezerra, tributary of rio Paranã, Monte Alegre de Goiás; MZUSP 43136, 1, 58.1, rio das Pedras, tributary of rio Paranã at São Teodoro Village. Roraima State. Branco basin: MZUSP 33483, 1, 255.7 mm SL, Cachoeira do Bem-Querer, rio Branco. GUYANA. Potaro-Siparuni. Essequibo basin: ANSP 179635, 1, 77.8 mm SL, Essequibo River in Kurukupari; ANSP 179626, 2, 94.6-99.0 mm SL, Pirara River, upper Takutu. SURINAME. Brokopondo. Suriname basin: MZUSP 65417, 1, 54.3 mm SL, Maykaboeka Creek at Gros Rosebel Area. Nickerie. Nickerie basin: MZUSP 41508, 3, 80.7-94.6 mm SL, Nickerie River. Saramacca. Saramacca basin: MZUSP 41510, 2, 126.9-192.3 mm SL, Toebaka Creek, Saramacca River; MZUSP 41512, 4, 58.7-108.0 mm SL, Coppename River. VENEZUELA. Amazonas. Orinoco basin: ANSP 164976, 4, 162.8-189.4 mm SL, tributary of rio Orinoco at sandy beach, circa of half-hour upstream from the Isla Temblador.

Diagnosis. Hoplias curupira differs from the other species of $H$. lacerdae group in always having four pores of the laterosensory canal along the ventral surface of the dentary that become gradually subdivided into four patches of multiple pores in specimens larger than $60 \mathrm{~mm}$ SL; a dark brown ground coloration of head and body; by having fewer lateral line scales (34-39 vs. 38-48 in remaining species of H. lacerdae group) and a wider head, with larger ranges of relative snout width and interorbital width (13.1-27.2\% and 16.0-35.5\% respectively, vs. $12.6-22.9 \%$ and $14.9-30.1 \%$ in the remaining species of $H$. lacerdae group) (Figs. 6-7). In addition, an anterior profile of head that is rounded in lateral view distinguished $H$. curupira from $H$. brasiliensis and $H$. intermedius, which have the anterior profile of head angular.

Description. Morphometric data presented in Table 5. Body cylindrical, deeper than wide. Greatest body depth at vertical through third scale anterior to dorsal-fin origin in specimens smaller than $85 \mathrm{~mm} \mathrm{SL}$, closer to dorsal-fin origin in larger specimens. Anterior profile of head rounded in lateral view, more angular in specimens smaller than 85 mm SL. Dorsal

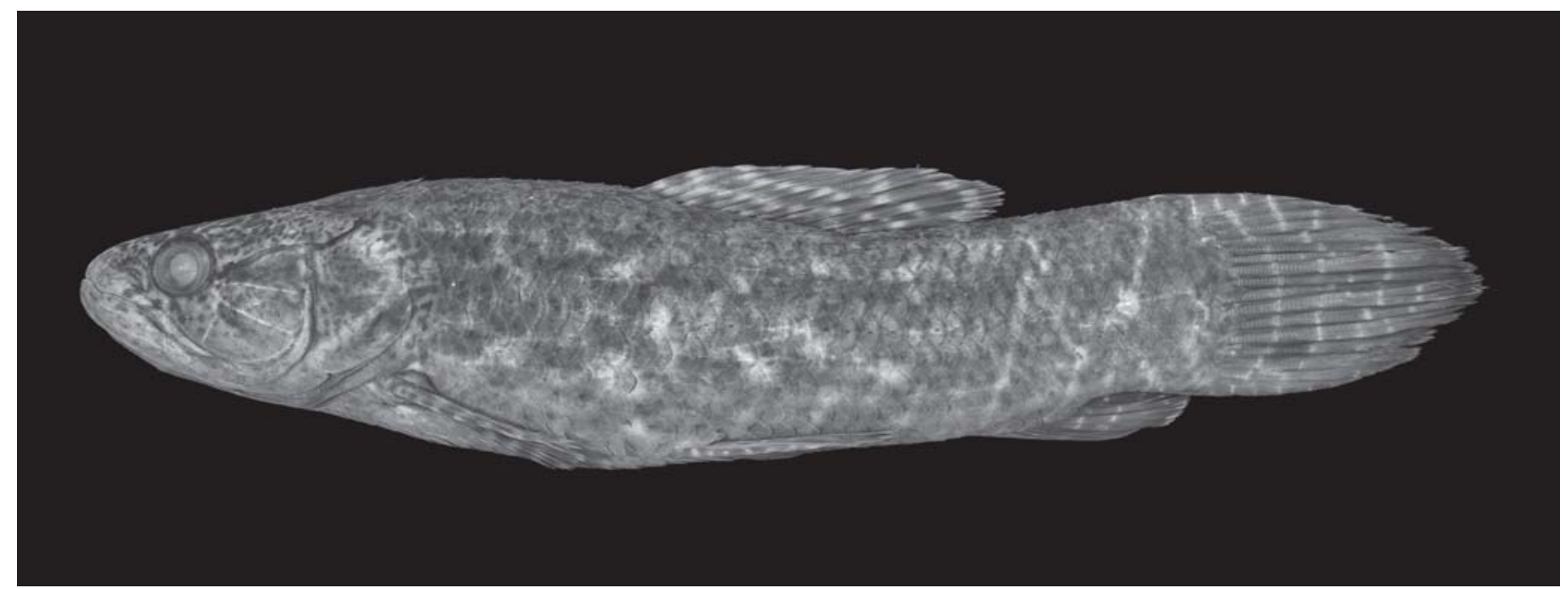

Fig. 5. Hoplias curupira, holotype, MZUSP 45582, 157.9 mm SL, rio Itacaiúnas, Caldeirão, Serra dos Carajás, Pará State, Brazil. 


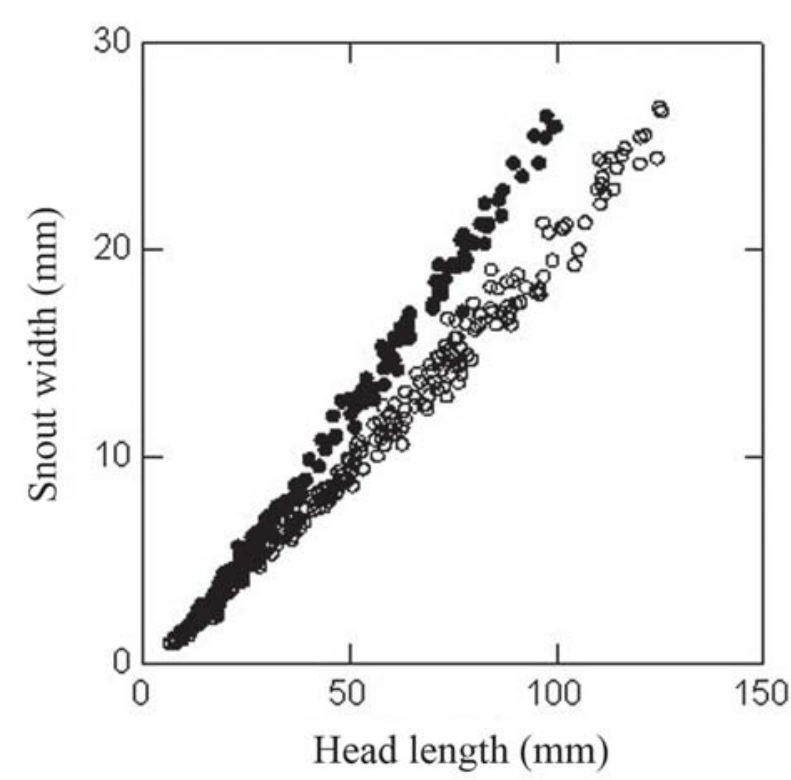

Fig. 6. Snout width vs. head length for Hoplias curupira (dots) and remaining species of the Hoplias lacerdae group (circles).

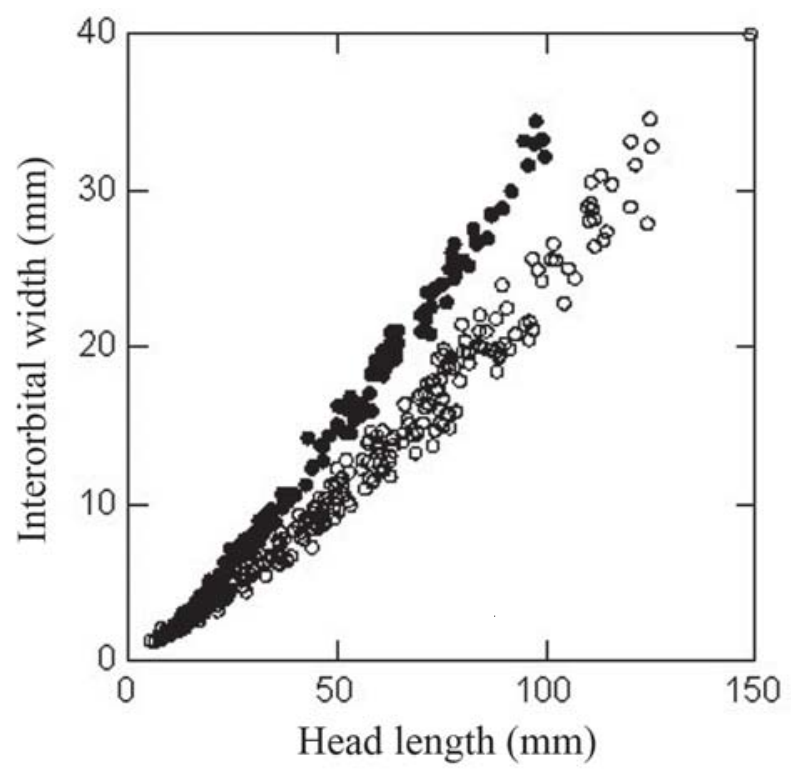

Fig. 7. Interorbital width vs. head length for Hoplias curupira (dots) and remaining species of Hoplias lacerdae group (circles).

profile of head almost straight. Dorsal margin of orbit reaching dorsal profile of head in specimens smaller than $85 \mathrm{~mm}$ SL, but falling short of dorsal profile of head in larger specimens (e.g., $160 \mathrm{~mm}$ SL). Head relatively broad, especially dorsally (Figs. 6-7). Dorsal profile of body convex from vertical through first series of scale of body to dorsal-fin origin; straight and posteroventrally inclined along dorsal-fin base; concave from vertical through base of last dorsal-fin ray to origin of dorsal most procurrent caudal-fin ray. Latter portion of profile slightly less concave in specimens smaller than $85 \mathrm{~mm}$ SL. Caudal peduncle robust, relatively deep. Ventral profile of lower jaw distinctly angular in region of dentary symphysis, convex from vertical through anterior nostril to posterior margin of lower jaw. Medial margins of contralateral dentaries running in parallel (Fig. 1a-c). Ventral profile of body slightly convex to pelvic-fin origin; approximately straight from latter point to anal-fin origin; straight and posterodorsally inclined along anal-fin base; slightly concave from last anal-fin ray to anterior most ventral procurrent caudal-fin ray.

Upper and lower jaws of similar size. Posterior portion of maxilla dorsally enlarged and extending medially to anterior margins of second and third infraorbitals. Upper and lower lips fleshy with short skin projections covering canines externally. Anterior nostril tubular with anterior slit along its distal half. Anterior and posterior nostrils situated along horizontal through center of orbit, anterior nostril at length one-half of orbital diameter from anterior margin of orbit; posterior nostril closer to anterior margin of orbit than anterior nostril. Eye proportionately larger in smaller specimens. Infraorbital bones well-developed and horizontally elongate. Infraorbitals 3, 4, and ventral portion of 5 partially covering preopercle. Ventral margin of infraorbital 3 convex. Posterior margin of infraorbital 4 relatively straight and margins of infraorbitals 5 and 6 slightly convex. Small specimens (ca. 85 $\mathrm{mm}$ SL) with infraorbital 3 not reaching orbital rim and with proximal ends of infraorbitals 2 and 4 in contact. Larger specimens (ca. $160 \mathrm{~mm} \mathrm{SL}$ ) with infraorbital 4 almost excluded from orbital rim.

Teeth in both jaws conical or canine. Premaxillary teeth in single row. First premaxillary tooth large canine, second and sixth teeth medium sized. Seventh tooth canine and almost as

Table 5. Morphometric data of Hoplias curupira. Standard length in mm; values 1-14 are percents of standard length and values $15-22$ are percents of head length. $\mathrm{n}=$ number of examined specimens.

\begin{tabular}{lccccc}
\hline & Holotype & $\mathrm{n}$ & Mean & Range & $\begin{array}{c}\text { Standard } \\
\text { deviation }\end{array}$ \\
\hline Standard length & 157.9 & 157 & - & $14.8-312.4$ & - \\
1. Body depth & 24.3 & 140 & 23.9 & $18.3-29.5$ & 2.5 \\
2. Head length & 33.0 & 156 & 33.5 & $30.2-36.9$ & 1.6 \\
3. Pectoral-fin length & 21.1 & 155 & 19.5 & $13.9-23.4$ & 1.4 \\
4. Pelvic-fin length & 21.1 & 156 & 20.5 & $16.9-25.8$ & 1.6 \\
5. Anal-fin length & 21.0 & 152 & 20.2 & $16.4-23.5$ & 1.3 \\
6. Dorsal-fin length & 34.6 & 155 & 33.3 & $27.4-40.2$ & 2.2 \\
7. Dorsal-fin base & 21.0 & 156 & 19.8 & $14.2-23.2$ & 1.4 \\
8. Anal-fin base & 10.5 & 155 & 10.4 & $8.0-13.2$ & 1.0 \\
9. Pre-pectoral distance & 30.3 & 153 & 30.9 & $27.4-38.3$ & 1.9 \\
10. Pre-pelvic distance & 56.3 & 156 & 55.3 & $50.6-60.1$ & 1.7 \\
11. Pre-dorsal distance & 50.8 & 156 & 51.8 & $47.4-56.3$ & 1.9 \\
12. Pre-anal distance & 84.2 & 156 & 81.3 & $69.2-88.2$ & 2.7 \\
13. Caudal-peduncle depth & 17.0 & 156 & 15.8 & $11.3-18.8$ & 1.2 \\
14. Caudal-peduncle length & 13.5 & 156 & 12.7 & $9.7-17.6$ & 1.1 \\
15. Head depth & 46.6 & 156 & 46.7 & $35.3-53.1$ & 3.7 \\
16. Snout length & 25.8 & 156 & 25.1 & $18.5-29.8$ & 2.4 \\
17. Snout width & 24.8 & 155 & 23.2 & $13.1-27.2$ & 2.7 \\
18. Snout depth & 24.7 & 156 & 21.3 & $12.4-26.9$ & 2.7 \\
19. Pre-nasal distance & - & 154 & 16.0 & $11.5-20.3$ & 1.8 \\
20. Orbital diameter & 22.2 & 156 & 23.6 & $17.4-32.5$ & 3.9 \\
21. Interorbital width & 30.8 & 156 & 27.9 & $16.0-35.5$ & 4.1 \\
22. Upper jaw length & 51.7 & 156 & 49.5 & $43.3-56.2$ & 2.1 \\
\hline
\end{tabular}


large as anterior most premaxillary canine. Third to fifth, eighth, and ninth premaxillary teeth small. Maxilla with single row of approximately 33 relatively small teeth, except for very well developed canine-like fourth tooth. Dentary with anteriorly, external row of teeth and posterior internal row. External series with three anterior small teeth, followed by two well developed canines, with posterior canine larger than anterior canine, and then 13 conical teeth. All slightly smaller than anterior most dentary canine. Internal series beginning at level of last conical tooth of external series and composed of approximately 16 very small teeth. Accessory ectopterygoid and ectopterygoid toothed. Ectopterygoid with series of small conical teeth along its ventrolateral margin and many smaller viliform teeth ventromedially. Endopterygoid edentulous.

Distal margins of all fins rounded. Total dorsal-fin rays 13-16 ( $=154$; ii,11-14; mode: ii,12, n = 84). Dorsal fin located at midbody, its origin at vertical through approximately third scale anterior on series along pelvic-fin origin. Length of longest dorsal-fin rays slightly more than one-half of body depth. Anal-fin base short. Total anal-fin rays 8-10 ( $\mathrm{n}=155$; ii,6-8; mode: ii,8, $\mathrm{n}=148$ ). Specimens larger than $160 \mathrm{~mm} \mathrm{SL}$ with tip of depressed dorsal fin extending beyond vertical through anal-fin origin. Few specimens with longest anal-fin rays (third- to sixth branched rays) reaching origin of anterior most ventral procurrent ray of caudal fin. Total pectoral-fin rays $11-14$ ( $\mathrm{n}=153$; $\mathrm{i}, 10-13$; mode: $\mathrm{i}, 11, \mathrm{n}=83$ ). Pectoral-fin origin located at vertical through posterior region of opercle. Tip of pectoral fin separated from pelvic-fin origin by four or five scales, and almost reaching vertical through dorsal-fin origin in some specimens larger than $160 \mathrm{~mm}$ SL. Pectoral, pelvic and anal fins of similar size. Pelvic-fin rays i,7 $(n=154$, i,6 in three specimens). Pelvic-fin origin situated at midbody and approximately three scales posterior to vertical through dorsal-fin origin. Tips of pelvic fin separated from vertical through anal-fin origin by three or four scales. Caudal-fin rays $\mathrm{i}, 14-16, \mathrm{i}(\mathrm{n}=145,14$ branched rays in seven specimens and 16 branched rays in one specimen).

Well developed cycloid scales imbricated along body. Dorsal scales begin in series at posterior margin of parietals and overlap supraoccipital spine. Last vertical series of scales on caudal peduncle forms slightly convex arch on caudal-fin base in lateral view. Anterior margin of scales with small recess and posterior margin rounded. Approximately eight radii extending from center of scale to its anterior margin and around eleven radii, some anastomosed, extending from center of scale to its dorsal, posterior, and ventral margins. Lateral line straight and complete, extending from posteroventral margin of supracleithrum to posterior most scale in body. Lateral line with 34-39 ( $n=143$, 39 in three specimens; mode: 36, $n=60)$ perforated scales (Table 2). Lateral-line scales with single laterosensory canal. Longitudinal series of scales between lateral line and dorsal-fin origin 4.5-5.5 ( $\mathrm{n}=152$; mode: 4.5 , $\mathrm{n}=$ 112). Longitudinal series of scales between lateral line and pelvic-fin origin 4.5-5.5 ( $\mathrm{n}=150$; mode: $4.5, \mathrm{n}=146)$. Longitudinal series of scales around caudal peduncle 18-20 ( $\mathrm{n}=150$; mode 20, $\mathrm{n}=144$ ).
Approximately 11 gill rakers on first epibranchial, most in form of small denticulated plates. Lower branch of first branchial arch with four to seven more elongate rakers and approximately 10 plate-like rakers $(n=148)$. Laterosensory canal along ventral surface of dentary in form of four well defined patches of several small pores in specimens larger than $100 \mathrm{~mm}$ SL (Fig. 1c); usually four pores of laterosensory canal, and some pores divided in two or three smaller pores, in specimens around $50 \mathrm{~mm}$ SL (Fig. 1a). Pores gradually more divided in specimens between $60-80$ mm SL (Fig. 1b) (Table 3).

Color in alcohol. Ground coloration of head and body dark brown, darker dorsally and paler ventrally. Ventral region almost as dark as dorsal portion in several specimens. Dark reticulated pattern present in specimens smaller than $20 \mathrm{~mm}$ SL; pattern expanding and becoming darker in larger specimens (ca. $90 \mathrm{~mm} \mathrm{SL}$ ), covering most of body in some of largest examined individuals. Dorsal surface of head dark brown, slightly lighter than remaining dorsal surfaces of body in some specimens, often with lighter reticulated pattern. Lips dark brown with alternating dark and light vertical bands in some specimens. Coloration of infraorbital region and dorsal surface of head similar. Many specimens with one or two dark stripes radiating posteriorly from eye across opercular series, more conspicuously in specimens with light brown coloration. Ground coloration of opercular series dark brown. Opercular membrane with same pattern as opercle.

All fins light brown to dark grey with white spots on rays and interradial membrane forming pattern of irregular light stripes. Three or four white stripes on dorsal fin, five white stripes on caudal fin and approximately four white stripes on anal fin. Ventral surfaces of pectoral and pelvic fins with same pattern as dorsal surfaces.

Distribution. Rivers of the Amazon basin including rios Capim, Tocantins, Xingu and Tapajós on the right bank of the rio Amazonas and rios Trombetas and Negro on the left bank, including upper tributaries of the rio Negro (rios Tiquié and Uaupés). In the rio Orinoco basin, Hoplias curupira occurs in the upper Orinoco, near the río Casiquiare. The species also occurs in coastal rivers of Guyana and Suriname, such as Essequibo, Demerara and Nickerie Rivers (Fig. 3).

Etymology. The specific name curupira, a noun in apposition, refers to the Curupira, a mythical creature of the Brazilian folklore that protects the forest. A Curupira is a small Amerindian child who has its feet turned backwards, making it difficult to follow its tracks.

Remarks. The distribution of Hoplias curupira greatly overlaps that of H. aimara, with the exception that the latter species is unknown from the rio Negro basin (including rio Branco) and upper rio Orinoco. These two species, however, do not seem to occur syntopically, as H. aimara is found 
predominantly in rapids and waterfalls (Mattox et al., 2006) while $H$. curupira prefers large rivers and igarapés (Lima et al., 2005). Despite the evident differences between these two taxa (see above), specimens of $H$. aimara are commonly mistaken as $H$. aff. lacerdae ( $=H$. curupira) in fishing magazines. Our data show that $H$. curupira does not grow as large as H. aimara, the true large trahira that is regarded as a good sport fish and pursued by anglers in Amazonian rivers such as rio Xingu.

Although most of the morphometric data from specimens presented herein overlap among different species, two characters can be used to diagnose $H$. curupira from congeners. Specimens of the taxon have broader heads compared to the remaining four species in the Hoplias lacerdae group, with this reflected in the snout width (13.127.2\% of head length) (Fig. 6) and the interorbital width (16.0$35.5 \%$ of head length) (Fig. 7), vs. the remaining species of the group (12.6-22.9\% and 14.9-30.1\% of head length respectively). The mean relative snout width of $H$. curupira is $23.2 \%$ ( standard deviation $=2.7)$ vs. $18.7 \%$ (standard deviation $=$ 1.9) in the remaining species of the Hoplias lacerdae group, and the mean relative interorbital width of $H$. curupira is $27.9 \%$ (standard deviation $=4.1$ ) vs. $21.1 \%$ (standard deviation $=2.9$ ) in the remaining species of Hoplias lacerdae group. Hoplias curupira is often referred as "cabeça chata" (flat headed), in reference to the larger width of its head compared to other species of Hoplias.

Hoplias curupira has a wide distribution in the Amazon Basin, and variation of the color pattern was detected from different localities. It is not possible, however, to define if this is due to ecological variation or indicative of a second species in the basin. Therefore the type series was restricted to rio Tocantins basin.

According to Lima et al. (2005), Hoplias curupira occurs in large rivers and igarapés, exhibits diurnal as well as nocturnal habits, is often seen in pairs, and probably spawns inside hollow logs. It feeds on various insects, larvae, small fishes, shrimps and worms, and also eats certain fruits.

\section{Hoplias intermedius (Günther, 1864) \\ Fig. 8}

Erythrinus brasiliensis: -Castelnau, 1855:56 [misidentification, occurrence in the rio Carandaí, rio Paraná drainage, differences from Erythrinus trahira].

Macrodon intermedius Günther, 1864: 282 [original description; type locality: rio Cipó, Minas Gerais State, Brazil; syntypes: BMNH 1861.5.16.6-7, dried and stuffed specimens]. -Steindachner, 1874: 26 [species list as synonym of Macrodon trahira]. -Eigenmann \& Eigenmann, 1889: 103 [species list as synonym of Macrodon malabaricus]. -Eigenmann, 1910: 448 [species list as synonym of Hoplias malabaricus]. -Fowler, 1950: 364 [species list, synonym of Hoplias malabaricus malabaricus]. -Godoy, 1975: 406 [synonym of Hoplias malabaricus malabaricus]. -Lütken, 2001: 78 [as synonym of Macrodon trahira]. -Oyakawa, 2003: 239 [as synonym of Hoplias microcephalus].

Hoplias lacerdae: -Britski, 1972: 81-82 [in part, species list, differences from $H$. malabaricus, occurrence in the rio Paraná basin]. -Bertollo et al., 1978 [occurrence in upper rio Grande, upper Paraná, karyotype description]. -Bizerril, 1994: 56 [in part, occurrence in rios Paraná and São Francisco]. -Penczak et al., 1998: 92 [occurrence in the rio Ivaí, rio Paraná basin]. -Agostinho \& Júlio Jr., 1999: 382 [occurrence in upper rio Paraná]. -Meschiatti et al., 2000: 135 [occurrence of juveniles in floodplains of rio MogiGuaçú, upper Paraná]. -Alves \& Pompeu, 2001 [occurrence in upper rio São Francisco]. -Barrella \& Petrere Jr., 2003: 65 [occurrence in the rio Tietê basin, upper rio Paraná]. Pompeu \& Alves, 2003: 133 [hypothesis of introduction into the rio São Francisco basin]. -Alvim \& Peret, 2004: 198 [diet in the rio São Francisco]. -Vieira et al., 2005: 80 [occurrence in upper reaches of rios São Francisco and Doce]. -Cunico \& Agostinho, 2006: 128 [occurrence in tributary to rio Ivaí, rio Paraná basin]. -Silva et al., 2006a: 832 [occurrence in the rio São Francisco]. -Silva et al.,

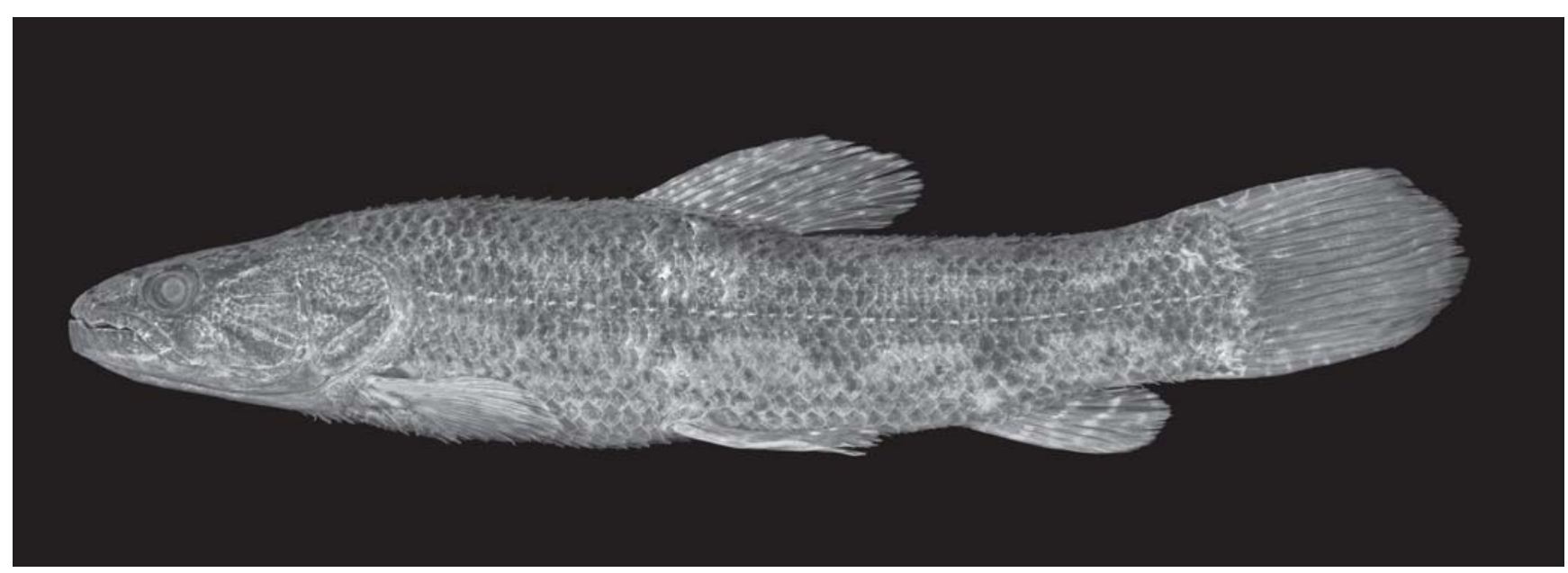

Fig. 8. Hoplias intermedius, MZUSP 69370, 169.3 mm SL, rio Suaçui Pequeno, Minas Gerais State, Brazil. 
2006b: 3572 [occurrence in the rio Tietê, upper rio Paraná]. Hoplias cf. lacerdae: -Britski et al., 1984:55 [identification key, occurrence in Três Marias Dam, rio São Francisco drainage].

Hoplias aff. lacerdae: -Sato \& Godinho, 1999:411 [occurrence in the rio São Francisco basin].

Lectotype. BRAZIL. Minas Gerais State. São Francisco basin: BMNH 1861.5.16.6, 533.4 mm SL, rio Cipó, no date, Ch. Cumberland. Dry and mounted specimen (Fig. 9), [designated herein].

Paralectotype. BRAZIL. Minas Gerais State. São Francisco basin: BMNH 1861.5.16.7, 279.4 mm SL, same locality and collector. Skin [designated herein].

Material examined. BRAZIL. Bahia State. São Francisco basin: MZUSP 94050, 1, $73.5 \mathrm{~mm} \mathrm{SL}$, rio Formoso, tributary to rio Corrente, Colônia do Formoso; MZUSP 94434, 15, 17.6-181.7 mm SL, riacho do Morro Furado, tributary to rio Corrente near mouth of Gruta do Morro Furado, Coribe; MZUSP 94667, 2, 14.8-27.7 mm SL, riacho do Morro Furado, tributary to rio Corrente, Coribe; MZUSP 94436, 2, 284.2-309.8 mm SL; MZUSP 94437, 1, 284.9 mm SL, Sobradinho Dam, rio São Francisco. Minas Gerais State. São Francisco basin: INPA 26894, 4, 242.7-282.0 mm SL; MCP 13994, 1, 448.4 mm SL; MCP 13995, 1, 367.2 mm SL; MZUSP 24638, 3, 275.8-374.4 mm SL; MZUSP 38639, 10, 235.8-349.3 mm SL, Três Marias Reservoir, rio São Francisco; MZUSP 38052, 1, 58.9 mm SL, Três Marias Reservoir near Morada Nova de Minas; MCP 14091, 1, 392.0 mm SL; MCP 14092, 1, 420.2 mm SL; MCP 14102, 1, 401.0 mm SL; rio São Francisco between Três Marias and Pirapora; MZUSP 1495, 1, 146.6 mm SL, rio São Francisco, Pirapora; MZUSP 25062, 1, $47.9 \mathrm{~mm}$ SL, córrego do Julião, on the road to Jaboticatubas; MZUSP 37157, 9, 35.3-47.7 mm SL, stream tributary to rio Paraopeba, Moeda; MZUSP 37252, 3, 130.4-162.7 mm SL, lagoa da Prata, rio São Francisco; MZUSP 38571, 2, 375.5-377.8 mm SL, córrego Água Limpa, tributary to rio Abaeté; MZUSP 39239, 1, 20.0 mm SL, lagoon on right bank of córrego Braço Grande, rio São Francisco; MZUSP 39275, 1, 105.0 mm SL, Ilha Grande, rio São Francisco; MZUSP 39381, 2, 16.4-53.2 mm SL, lagoa do Praiano, left bank of rio São Francisco; MZUSP 39565, 1, 102.6 mm SL, córrego Ribeiro Manso, tributary to rio Abaeté; MZUSP 39571, córrego Água Limpa, tributary to rio Abaeté; MZUSP 39628, 1, 127.2 mm SL, córrego Capivara, tributary to rio Abaeté; MZUSP 39652, 2, 140.1-196.9 mm SL, córrego Chumbo, tributary to rio Abaeté; MZUSP 39700, 1, 240.8 mm SL, rio São Francisco at Pontal do Abaeté; MZUSP 39741, 4, 169.8-265.9 mm SL, rio São Francisco and tributaries, Formoso Hydroelectric Station area; MZUSP 39779, 1, 22.5 mm SL, rio São Francisco at mouth of rio Formoso; MZUSP 47268, 2, 42.6-128.2 mm SL, stream under bridge of BR 135 road, between Corinto and Augusto de Lima; MZUSP 47325, 1, 67.8 mm SL, stream tributary to rio Jequitaí, on BR 135 road, between Buenópolis and Engenheiro Dolabela; MZUSP 54696, 2, 40.5-42.1 mm SL, rio Cipó, circa $10 \mathrm{~km}$ southeast of BR 259 road, Presidente Juscelino; MZUSP 73655, 1, 105.7 mm SL, rio Cipó, Presidente Juscelino; MZUSP 73735, 1, 164.2 mm SL, rio Bicudo, Fazenda Bom Jardim, Corinto; MZUSP 73837, 1, 249.9 mm SL, Lagoa Santa, rio das Velhas drainage; MZUSP 73839, 1, 274.8 mm SL, rio Curimataí, Fazenda Vitória, Augusto de Lima; MZUSP 73842, 1, 259.9 mm SL, central lagoon in Lagoa Santa; MZUSP 79247, Gruta Morena, Cordisburgo; MZUSP 86019, 1, 73.8 mm SL, rio Verde Grande, Montes Claros; MZUSP 94433, 2, 45.0-52.2 mm SL, lagoa Azul, rio das Velhas Basin, Cordisbugo; MZUSP 94435, 6, 34.2-257.2 mm SL, ribeirão da Onça, tributary to rio das Velhas, Cordisburgo; Minas Gerais State. Jequitinhonha basin: MZUSP 38830, 3, 147.3-221.7 mm SL, rio Araçuai downstream from the rio Fanado, Santa Rita. Minas Gerais State. Doce basin: MZUSP 74659, 1, 29.6 mm SL, rio Guanhães, Dores de Guanhães; MZUSP 75289, 2, 27.5-68.0 mm SL, rio Santo Antônio, Fazenda Campinas, Conceição do Mato Dentro; MZUSP 75331, 1, 276.7 mm SL, rio Santo Antônio, Santo Antônio; MZUSP 73113, 1, 313.4 mm SL, córrego da Fonseca, rio Santo Antônio, 11 km from Santo Antônio, São Sebastião do Rio Preto; MZUSP 75357, 1, 160.1 mm SL, rio Santo Antônio, Santo Antônio; MZUSP 80937, 1, 355.0 mm SL, rio Tronqueiras, São José de Tronqueiras near border with Coroací, Governador Valadares; MZUSP 69329, 2, 21.1-25.9 mm SL, rio Suaçuí Pequeno upstream from waterfall, Coroaci; MZUSP 69357, 2, 17.3-25.4 mm SL, rio Suaçuí Pequeno, upstream from and near the bridge of Procópio, Coroaci; MZUSP 69370, 1, 169.3 mm SL, rio Suaçuí Pequeno, downstream from the bridge of Procópio, Coroaci; MZUSP 66196, 2, 28.1-89.6 mm SL, rio Suaçuí Grande, downstream from the Traíra II Hydroelectric Station, Peçanha; MZUSP 87813, 1, $102.1 \mathrm{~mm}$ SL, stream tributary to rio Santo Antônio, Serro; MZUSP 87816, 1, 172.4 mm SL, small waterfall in córrego Claudiano, tributary to rio do Peixe, rio Santo Antônio drainage, Serro; MZUSP 87824, 1. 71.1 mm SL, Cachoeira do Cancão, rio Mãe d'Água, tributary to rio Santo Antônio, Santo Antônio do Itambé. Minas Gerais State. Paraíba do Sul basin: MZUSP 81011, 2, 248.7-267.2 mm SL, rio Glória, tributary to rio Muriaé, Muriaé, rio Paraíba do Sul basin. Minas Gerais State. upper Paraná basin: MZUSP 44019, 1, 116.7 mm SL, Camargos Reservoir, rio Grande, São João del Rei; MZUSP 51460, 4, 201.5277.5 mm SL, rio Grande, Itutinga Hydroelectric Station; MZUSP 51469, 1, 142.5 mm SL, rio Pará, Cajuru Hydroelectric Station, Carmo do Cajuru; MZUSP 51994, 4, 140.1-290.6 mm SL, Camargos Reservoir, rio Grande; MZUSP 38638, 1, $312.1 \mathrm{~mm}$ SL, rio Paranaíba, Bocaina Hydroelectric Station. São Paulo State. upper Paraná basin: MZUSP 23006, 2, 252.8-430.5 mm SL; MZUSP 24827, 23, 135.2-322.9 mm SL; MZUSP 45580, 1, 315.0 mm SL, rio Pardo, Limoeiro Hydroelectric Station, São José do Rio Pardo. Paraná State. upper Paraná basin: MZUSP 38570, 1, $113.6 \mathrm{~mm}$ SL, mouth of rio Cantú, tributary to rio Piquirí, Campina da Lagoa; MZUSP 39780, 2, 171.8-245.8 mm SL, rio Piquirí, Campina da Lagoa.

Diagnosis. Hoplias intermedius differs from the others species of the $H$. lacerdae group, but $H$. australis and $H$. lacerdae, in the number of scales along lateral line (42-46 vs. 38-43 in H. brasiliensis and 34-39 in H. curupira). It can be further distinguished from $H$. australis and $H$. lacerdae, in the number of pores of the laterosensory system along the ventral surface of dentary (4-6 vs. always 5 and 6-8 respectively). The shape of anterior profile of head further distinguished $H$. intermedius from $H$. australis (angular $v$ s. rounded respectively).

Description. Morphometric data presented in Table 6. Body cylindrical, deeper than wide. Greatest body depth at vertical through fifth scale anterior to dorsal-fin origin in specimens 
Table 6. Morphometric data of Hoplias intermedius. Standard length in mm; values 1-14 are percents of standard length and values 15-22 are percents of head length. $\mathrm{n}=$ number of examined specimens.

\begin{tabular}{lcccc}
\hline & $\mathrm{n}$ & Mean & Range & $\begin{array}{c}\text { Standard } \\
\text { deviation }\end{array}$ \\
\hline Standard length & 99 & - & $16.4-448.4$ & - \\
1. Body depth & 95 & 20.8 & $15.3-26.5$ & 2.5 \\
2. Head length & 99 & 31.4 & $28.8-36.9$ & 1.8 \\
3. Pectoral-fin length & 90 & 18.4 & $16.2-22.3$ & 1.2 \\
4. Pelvic-fin length & 98 & 18.9 & $15.3-22.4$ & 1.2 \\
5. Anal-fin length & 98 & 18.2 & $13.6-25.1$ & 1.5 \\
6. Dorsal-fin length & 99 & 28.5 & $23.6-33.7$ & 1.9 \\
7. Dorsal-fin base & 99 & 16.8 & $13.4-20.5$ & 1.2 \\
8. Anal-fin base & 99 & 9.2 & $7.3-11.5$ & 0.8 \\
9. Pre-pectoral distance & 98 & 29.0 & $24.8-36.2$ & 2.4 \\
10. Pre-pelvic distance & 99 & 55.7 & $50.0-61.7$ & 1.6 \\
11. Pre-dorsal distance & 99 & 50.5 & $46.3-56.0$ & 2.1 \\
12. Pre-anal distance & 99 & 81.1 & $72.8-87.2$ & 2.4 \\
13. Caudal-peduncle depth & 98 & 13.6 & $9.6-15.4$ & 1.2 \\
14. Caudal-peduncle length & 99 & 13.4 & $10.1-15.3$ & 1.1 \\
15. Head depth & 99 & 42.2 & $34.5-48.8$ & 2.5 \\
16. Snout length & 98 & 24.2 & $15.3-28.4$ & 2.4 \\
17. Snout width & 97 & 18.9 & $12.6-22.1$ & 2.1 \\
18. Snout depth & 97 & 19.7 & $10.3-24.2$ & 2.6 \\
19. Pre-nasal distance & 97 & 14.8 & $9.5-19.3$ & 2.0 \\
20. Orbital diameter & 98 & 20.9 & $13.7-35.8$ & 5.4 \\
21. Interorbital width & 99 & 22.2 & $15.1-28.0$ & 2.8 \\
22. Upper jaw length & 99 & 47.5 & $39.1-57.9$ & 2.9 \\
\hline
\end{tabular}

smaller than $40 \mathrm{~mm}$ SL, closer to dorsal-fin origin in larger specimens. Anterior profile of head rounded in lateral view in specimens smaller than $40 \mathrm{~mm}$ SL, more angular in larger specimens. Dorsal profile of head varying from slightly convex in specimens smaller than $40 \mathrm{~mm}$ SL to gradually becoming straighter in larger specimens. Dorsal margin of orbit located at horizontal through of dorsal profile of head in specimens smaller than $130 \mathrm{~mm}$ SL, but not reaching dorsal profile of head in larger specimens (ca. $300 \mathrm{~mm} \mathrm{SL}$ ). Dorsal profile of body slightly convex from vertical through first series of scale of body to dorsal-fin origin; straight and posteroventrally inclined along dorsal-fin base; straight and less inclined to slightly concave from vertical through base of last dorsal-fin ray to origin of dorsal most procurrent caudal-fin ray. Ventral profile of lower jaw distinctly angular in region of mandibular symphysis, straight to slightly inclined from vertical through anterior nostril to posterior margin of lower jaw. Medial margins of contralateral dentaries running in parallel (Fig. 1a-c). Ventral profile of body slightly convex to pelvic-fin origin; approximately straight to slightly convex from latter point to anal-fin origin; straight and posterodorsally inclined along anal-fin base; slightly concave from base of last anal-fin ray to anterior most ventral procurrent caudal-fin ray.

Upper and lower jaws of similar size in specimens smaller than $40 \mathrm{~mm}$ SL, upper jaw gradually becoming shorter than lower jaw in larger specimens. Posterior portion of maxilla dorsally enlarged and extending medial to anterior margins of second and third infraorbitals. Upper and lower lips fleshy with short projections of skin covering canines externally. Anterior nostril tubular with anterior slit along its distal half. Anterior and posterior nostrils situated along horizontal through center of orbit, anterior nostril located at two-thirds of orbital diameter from anterior margin of orbit; posterior nostril situated midway between anterior nostril and anterior margin of orbit. Eye proportionately larger in smaller specimens. Infraorbital bones well-developed and horizontally elongate. Infraorbitals 3,4 , and ventral portion of 5 partially covering preopercle. Anteroventral margin of infraorbital 3 relatively straight and posteroventral margin convex. Posterior margin of infraorbitals 4, 5, and 6 slightly convex. Small specimens (ca. $40 \mathrm{~mm} \mathrm{SL}$ ) with infraorbital 3 barely reaching orbital rim and proximal ends of infraorbitals 2 and 4 almost in contact. Larger specimens (ca. $130 \mathrm{~mm} \mathrm{SL}$ ) with infraorbitals 3 and 4 completely excluded from orbital rim and infraorbital 5 progressively separated from rim in larger specimens. Proximal ends of infraorbitals 2 and 6 almost meeting in some of the largest specimens examined (ca. 300 mmSL).

Teeth in both jaws conical or canine. Premaxillary teeth in single row. First premaxillary tooth large canine, second and seventh teeth medium sized. Eighth tooth canine almost as large as anterior most premaxillary canine. Third to sixth, and ninth premaxillary teeth small. Maxillary with single row of approximately 32 relatively small teeth, except for very well developed canine-like fourth tooth. Dentary with anterior external row of teeth and posterior internal row. External series with three anterior small teeth, followed by two well developed canines with posterior canine larger than anterior canine, and then 11 conical teeth slightly smaller than anterior most dentary canine. Internal series beginning at level of last conical tooth of external row and composed of approximately 18 very small teeth. Accessory ectopterygoid and ectopterygoid toothed. Ectopterygoid with series of small conical teeth along ventrolateral margin and many smaller viliform teeth on ventromedial surface. Endopterygoid edentulous.

Distal margins of all fins rounded. Total dorsal-fin rays 13-15 ( $\mathrm{n}=98$; ii,11-13; mode: ii,12, $n=44)$. Dorsal fin located at midbody, its origin at vertical through approximately fourth scale anterior on series along pelvic-fin origin. Longest dorsalfin ray approximately three-quarters of body depth. Anal-fin base short. Total anal-fin rays 9-11 ( $\mathrm{n}=97$; ii,7-9; mode: ii,8, $\mathrm{n}$ = 88). Tip of depressed dorsal fin reaching vertical through anal-fin origin in small specimens $(<130 \mathrm{~mm} \mathrm{SL}$ ) but falling short of that point in larger specimens. Total pectoral-fin rays 12-14 ( $=89$; i,11-13; mode: i,11, $n=55$ ). Pectoral-fin origin located at vertical through median region of opercle. Tip of pectoral fin separated from pelvic-fin origin by four to six scales. Pectoral and pelvic fins of similar size and slightly smaller than anal fin. Pelvic-fin rays i,7 ( $n=97, i, 8$ in one specimen). Pelvic-fin origin situated at midbody and approximately four scales posterior to vertical through dorsalfin origin. Tip of pelvic fin separated from vertical through anal-fin origin by four or five scales. Caudal-fin rays i,15, i ( $=$ 
88,13 branched rays in one specimen and 14 branched rays in six specimens).

Well developed cycloid scales imbricated along body. Dorsal scales begin in series at posterior margin of parietals and overlap supraoccipital spine. Last vertical series of scales on caudal peduncle forms slightly convex arch on caudal-fin base in lateral view. Anterior margin of scales with small recess and posterior margin rounded. Approximately eight radii extending from center of scale to its anterior margin and around eighteen radii, some anastomosed, extending from center of scale to its dorsal, posterior, and ventral margins. Lateral line straight and complete, extending from posteroventral margin of supracleithrum to posterior most scale in body. Lateral line with 42-46 ( $\mathrm{n}=90,42$ in five specimens and 46 in four specimens; mode: $44, \mathrm{n}=36$ ) perforated scales (Table 2). Lateral-line scales with single laterosensory canal. Longitudinal series of scales between lateral line and dorsalfin origin 5.5-6.5 ( $\mathrm{n}=92$; mode: $5.5, \mathrm{n}=86$ ). Longitudinal series of scales between lateral line and pelvic-fin origin 4.5$5.5(n=93$; mode: $5.5, n=75$ ). Longitudinal series of scales around caudal peduncle $20(\mathrm{n}=92)$.

Approximately 9 gill rakers on first epibranchial, most in form of small denticulated plates. Lower branch of first branchial arch with five or six more elongate rakers and approximately 10 plate-like rakers ( $\mathrm{n}=96)$. Laterosensory canal along ventral surface of dentary with 4-6 pores ( $\mathrm{n}=97$; mode: $5, \mathrm{n}=74$ ) (Table 3).

Color in alcohol. Ground coloration of head and body dark to light brown, darker dorsally and paler ventrally. Ventral region white in several specimens. Approximately seven dark parallel diagonal bars along dorsal region, bars extending anteroventrally to just below lateral line. Diagonal bars in many specimens continuing posteroventrally to approximately two longitudinal scale series below lateral line, resulting in chevron-like pattern. Dorsal portions of bars more evident than ventral region. Bars more conspicuous in specimens with light brown ground coloration. Dorsal surface of head dark brown. Lips with alternating dark and light vertical bands, but completely black in some of largest specimens examined (ca. $300 \mathrm{~mm} \mathrm{SL}$ ). Ventral surface of dentaries varying from white in small specimens ( $c a .40 \mathrm{~mm} \mathrm{SL}$ ), to alternating dark and light transverse stripes in specimens around 130 $\mathrm{mm}$ SL, to completely dark in larger specimens. Coloration of infraorbital region and dorsal surface of head similar. Many specimens with two dark stripes radiating posteriorly from eye along infraorbital 6 and dorsal portion of infraorbital 3. Ground coloration of opercular series dark brown. Opercular membrane usually lighter than opercle.

All fins light brown, lighter than body in specimens smaller than $130 \mathrm{~mm}$ SL, with dark spots on rays and interradial membranes forming pattern of irregular dark stripes. Stripes on anal and caudal fins wider and more regular than those on dorsal fin. Ventral surfaces of pectoral and pelvic fins either lighter than, or with same pattern as, dorsal surface, but with pattern less conspicuous. Fins of largest specimens ( $c a .300$ $\mathrm{mm}$ SL) usually darker than rest of body.

Distribution. In the rio São Francisco basin and upper reaches of rio Paraná basin, including rios Grande, Paranaíba and Piquiri. Hoplias intermedius also occurs in tributaries of rio Doce, Minas Gerais State (Fig. 3).

Remarks. Syntypes of Macrodon intermedius are deposited in the BMNH collection, and permit its clear placement in the Hoplias lacerdae group. Data presented herein matches information from the original description of $M$. intermedius. Oyakawa (1990) included the nominal species Erythrinus microcephalus Agassiz, 1829 and Macrodon intermedius Günther, 1864 in the Hoplias lacerdae group, with latter being considered a junior synonym of the former (Oyakawa, 2003). These names are available for the taxon occurring in the upper rio São Francisco drainage, since E. microcephalus was described from "rio São Francisco" and M. intermedius from "rio Cipó”, one of its tributaries. As discussed above, many specimens of species described by Spix and Agassiz (1829) were lost during World War II, as well as the holotype of Erythrinus microcephalus is also missing (Terofal, 1983; Kottelat, 1988). Unlike the situation with Erythrinus brasiliensis (see above), the original description of E. microcephalus, although mentioning that the tongue is edentate, is unclear as to the alignment of the contralateral dentaries noting only that "branches of the lower jaw narrow and convex throughout their length, farther apart when the mouth is closed and distant from the other by a greater space than their transverse diameter" [our translation]. This makes it difficult to determine whether Hoplias microcephalus belongs to the $H$. lacerdae or to the $H$. malabaricus species groups. Neither Hoplias microcephalus nor $H$. intermedius have been recently used, except for a catalog based on preliminary data (Oyakawa, 2003), but previous authors included both epithets as synonyms of $H$. malabaricus (e.g. Steindachner, 1874; Lütken, 2001). The younger name, $H$. intermedius is certainly a member of the $H$. lacerdae group whereas the older one, $H$. microcephalus cannot be unambiguously assigned to this group. Since neither these names has been used recently, $H$. intermedius is herein chosen to designate this taxon.

In describing Macrodon intermedius, Günther (1864) cited two specimens, but made no reference to either being the holotype, and both are thus syntypes of the species. Following Article 74 of the International Code of Zoological Nomenclature (ICZN, 1999), one of the syntypes is designated a lectotype (BMNH 1861.5.16.6) (Fig. 9), and the other becomes a paralectotype (BMHN 1861.5.16.7).

Hoplias intermedius has an interesting disjunct distribution, occurring in the upper stretches of rio São Francisco, rio Doce and rio Paraná. In the latter basin, the species is not known to occur downstream of the Sete 


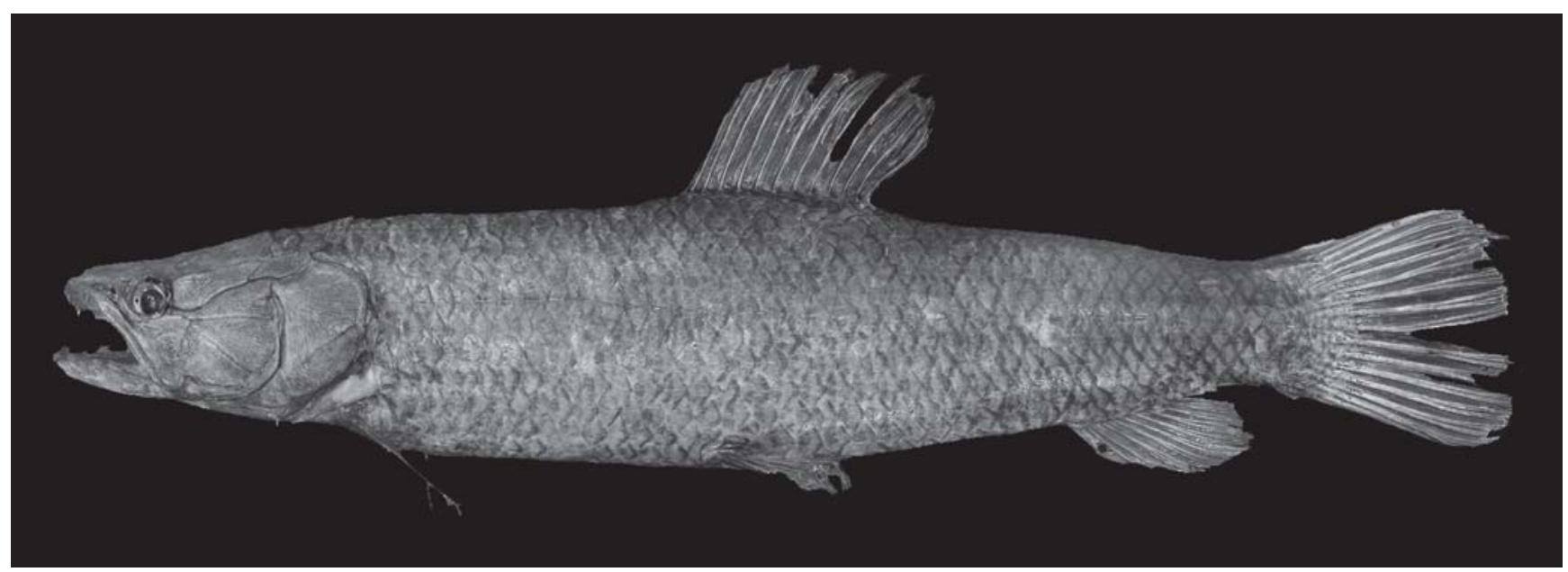

Fig. 9. Hoplias intermedius (lectotype of Macrodon intermedius) BMNH 1861.5.16.6, 533.4 mm SL, rio Cipó, Minas Gerais State, Brazil.

Quedas. Similar distributions are reported for other fish species (Menezes, 1988; Vari \& Harold, 2001). Dergam et al. (2002) demonstrated that populations of $H$. malabaricus from the upper rio Doce, upper rio Paraná, and upper rio Paraíba do Sul are genetically close, indicating a possible common origin or recent exchanges between these basins. Vieira et al. (2005) also suggested a common ancestry between the rios São Francisco and Doce based on their ichthyofauna.

Current knowledge of the geological history of eastern South America indicates that the origin of coastal rivers involved successive erosion of the eastern margin of the platform associated with consequent upland river capture, giving rise to the various independent basins draining into the Atlantic Ocean (Potter, 1997; Ribeiro, 2006). According to these authors, six major uplift events created megadomes that worked synergistically with marginal erosion and upland stream capture along the Atlantic coast of South America when the latter and Africa were separated during the opening of the Atlantic Ocean. One of these megadomes, the "Mantiqueira-Angola", is represented in Brazil by highlands extending from São Paulo and Rio de Janeiro states north to Minas Gerais state, and was responsible for isolating the upper stretches of the rios São Francisco, Paraná and Doce. Therefore, it is possible that the disjunct distribution pattern of Hoplias intermedius, as well as of other examples cited above, results from a common history of these basins.

Goeldi (1898) cited Macrodon intermedius in the Ilha de Marajó, in the mouth of rio Amazonas. Under current understanding of the distribution of $\mathrm{H}$. intermedius it is clear that these records of the species in the Amazon basin were based on misidentifications. The only species of $H$. lacerdae group occurring in the vicinity of Ilha de Marajó is $H$. curupira, described in the present study. However, the number of lateral line scales (43) reported by Goeldi (1898) does not match with the range registered for $H$. curupira (34-39).

Alves \& Pompeu (2001), Pompeu \& Alves (2003), Vieira et al. (2005) and Silva et al. (2006a) stated that Hoplias aff. lacerdae $(=H$. intermedius) was introduced into rio São Francisco because it was originally described from rio Ribeira de Iguape and was missing from earlier ichthyological surveys in the rio São Francisco. The absence of $H$. intermedius in previous reports of the São Francisco fish fauna is due to the fact that past naturalists failed to recognize two groups of species in that basin based on the orientation of the contralateral dentaries (Lütken, 2001).This resulted in taxonomic confusion and the placement of $H$. intermedius in the synonym of $H$. malabaricus. After these two groups had been formally defined by Oyakawa (1990), Hoplias aff. lacerdae (= Hoplias intermedius) began to be included in the ichthyological surveys of the rio São Francisco, but was erroneously regarded as an exotic species introduced from the rio Ribeira de Iguape basin.

Although several karyotypes have been reported for the Hoplias malabaricus group (e.g. Bertollo et al., 1983; Dergam \& Bertollo, 1990; Bertollo et al., 2000), only one karyotype has been described for specimens of the Hoplias lacerdae group collected in the upper rio Paraná basin (Bertollo et al., 1978). The diploid number cited by these authors, $2 n=50$, is regarded herein as belonging to $H$. intermedius, as that species occurs in the upper rio Paraná basin. Further karyotype and molecular studies involving Hoplias intermedius from rio São Francisco and rio Doce basins would greatly aid in the knowledge of this species regarding its disjunct distribution.

Hoplias intermedius inhabits main rivers channels and marginal lagoons (Vieira et al., 2005). Juveniles were captured in floodplain lakes (Meschiatti et al., 2000). The species is common in reservoirs (e.g. Cunico \& Agostinho, 2006; Silva et al., 2006a) and has economic importance (Alves \& Pompeu, 2001; Vieira et al., 2005). Its piscivorous habit (Alvim \& Peret, 2004) makes it vulnerable to the bioaccumulation of mercury. In the rio das Velhas, a tributary to the rio São Francisco, its flesh had the highest permitted level of mercury (Alves \& Pompeu, 2001). 


\section{Hoplias lacerdae Miranda-Ribeiro, 1908 Fig. 10}

Hoplias lacerdae Miranda-Ribeiro, 1908: 3 [original description, type locality: rio Ribeira de Iguape, Iporanga, São Paulo state, Brazil; Holotype: MNRJ 211, dried specimen]. -Eigenmann, 1909: 374 [reference, occurrence in the rio Ribeira de Iguape]. -Eigenmann, 1910: 448 [reference, occurrence in the rio Ribeira de Iguape]. -Fowler, 1950: 364 [in species list]. -Azevedo et al., 1965: 103 [redescription, differences from $H$. malabaricus]. -Britski, 1972: 81-82 [in part, species list, differences from $H$. malabaricus, occurrence in the rio Ribeira de Iguape basin]. -Géry et al., 1987: 368 [identification key]. -Bizerril, 1994: 56 [in part, occurrence in eastern river basins]. -Bizerril \& Lima, 2000: 107 [occurrence in the rio Ribeira de Iguape]. Oyakawa, 2003: 239 [species list, distribution]. -Oyakawa et al., 2006: 166 [species list with pictures, differences from H. malabaricus]. -Oyakawa \& Netto-Ferreira, 2007: 64 [species list, distribution]. -Menezes et al., 2007: 153 [typelocality, distribution].

Hoplias aff. lacerdae: -Malabarba, 1989: 127 [remarks on occurrence in the rio Jacuí, Rio Grande do Sul]. -Zaniboni Filho et al., 2004: 104 [biological and ecological features, with picture].

Hoplias lacertae: -Géry, 1977: 102 [unavailable name, lapsus calami, remarks on validity of name, identification key].

Holotype. BRAZIL. São Paulo State: MNRJ 211, 750.0 mm SL, rio Ribeira de Iguape, Iporanga, no date, R. Krone. (Fig. 11).

Material examined. BRAZIL. São Paulo State. Ribeira de Iguape basin: MNRJ 11217, 1, 443.0 mm SL, rio Juquiá, tributary to rio Ribeira de Iguape, Registro; MZUSP 7900, 1, 625.0 mm SL; MZUSP 7901, 1, 380.3 mm SL, rio Ribeira de Iguape; MZUSP
38569, 1, 157.2 mm SL, rio Ribeira de Iguape, Registro; MZUSP 7902, 1, 367.0 mm SL; MZUSP 37989, 2, 279.4-417.2 mm SL, rio Pardo on the road Iporanga-Barra do Turvo, $14 \mathrm{~km}$ from Barra do Turvo; MZUSP 45433, 1, 234.9 mm SL, rio Ribeira de Iguape by rio Pilões, Eldorado; MZUSP 51104, 1, head length 244.5 mm SL, rio Juquiá, Registro; MZUSP 61748, 1, 150.5 mm SL, rio André Lopes, Iporanga; MZUSP 72953, 1, 388.6 mm SL, rio Jacupiranga, Registro. Santa Catarina State. Uruguay basin: MCP 12339, 1, 202.0 mm SL; MCP 12365, 1, 65.3 mm SL, rio Canoas between Vargem and São José do Cerrito, Campos Novos; MCP 12731, 1, 295.5 mm SL; MCP 12732, 1, 224.53 mm SL; MCP 12879, 2, 130.7-245.0 mm SL, rio Canoas at Passo do Canoas, SC-458, Campos Novos; MCP 12338, 1, 218.8 mm SL; MCP 12745, 2, 242-249.3 mm SL; MCP 13143, 1, 152.9 mm SL; MCP 12878, 3, 297.2-344.4 mm SL, rio Canoas, on Abdon Batista-Anita Garibaldi road, Campos Novos; MCP 12884, 1, 387.8 mm SL; MCP 12898, 3, 63.4-147.1 mm SL; MCP 41003, 1, 115.3 mm SL, rio Canoas, on Abdon Batista-Anita Garibaldi road; MCP 13420, 1, 180.0 mm SL; MCP 18427, 1, 203.8 mm SL; MCP 18828, 1, 226.6 mm SL; MCP 18925, 2, 242.6-301.0 mm SL; MCP 19151, 1, 402.1 mm SL; MCP 19035, 2, 243.1-325.6 mm SL, rio do Peixe in Volta Grande, Concórdia; MCP 19146, 1, 411.5 mm SL; MCP 41004, 1, 253.3 mm SL, rio Riacho Grande, on Piritiba-BR 153 road, Concórdia; MCP 19147, 1, 415.1 mm SL, rio Uruguai in Itá; UFRGS 7530, 1, 238.6 mm SL, rio Jacutinga near water capture, Concórdia. Rio Grande do Sul State. Uruguay basin: INPA 26892, 1, 144.1 mm SL; MCP 12719, 3, 130.5-185.3 mm SL, arroio Passo Alto, São Nicolau; MCP 10896, 3, 110.0-207.7 mm SL, rio Garupá, tributary to rio Quaraí, on Uruguaiana-Quaraí road; MCP 11226, 1, 142.3 mm SL, tributary to rio Quaraí-Mirim on Quaraí-Alegrete road, Alegrete; MCP 11231, 4, 120.0-179.9 mm SL; MNRJ 30393, 1, 145.7 mm SL, rio Garupá on Alegrete-Quaraí border; MCP 12089, 1, 288.8 mm SL; MCP 13421, 1, 301.1 mm SL; MNRJ 30394, 1, 302.1 mm SL, rio Ligeiro, on Marcelino RamosMaximiliano de Almeida road; MZUSP 37254, 1, 107.6 mm SL; MZUSP 43683, 1, 196.3 mm SL, rio Garupá, tributary to rio Quaraí; MCP 12674, 1, 284.3 mm SL, arroio Canoin on PirapóSão Nicolau road, São Nicolau, Rio Grande do Sul; MCP 13210, 1, 285.8 mm SL, mouth of rio Ijuí-Mirim, Pirapó; MCP 14228, 1,

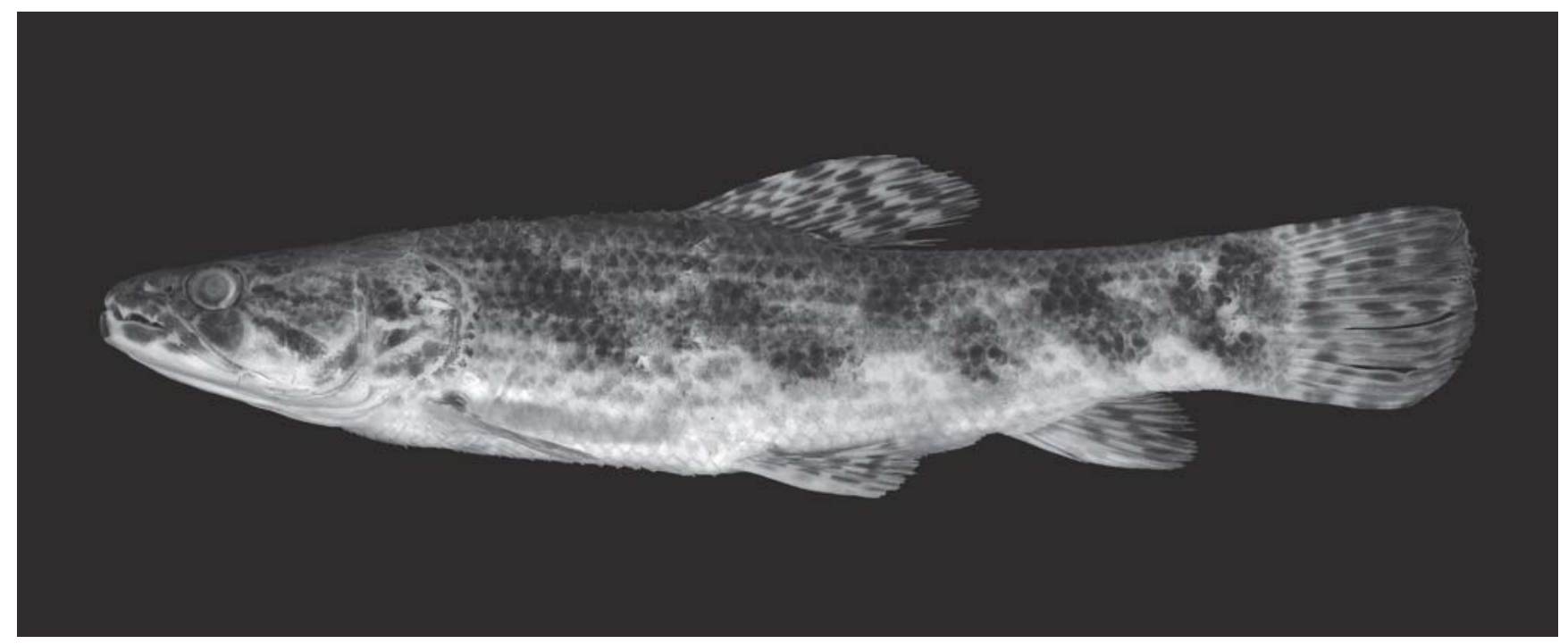

Fig. 10. Hoplias lacerdae, MZUSP 61748, 150.5 mm SL, rio Ribeira de Iguape, São Paulo State, Brazil. 
28.4 mm SL, tributary to rio Negro on Bagé-Aceguá road; MCP 14280, 1, 332.2 mm SL, arroio Ibicuí da Faxina, Santana do Livramento; MCP 16802, 2, 304.6-349.2 mm SL, rio Ijuizinho near Cermissões dam; MCP 18875, 1, 250.3 mm SL, rio Uruguai in Marcelino Ramos; MCP 16818, 276.8 mm SL, rio Buricá near CERTHIL dam, Independência; MCP 18924, 1, 251.4 mm SL, rio Uruguai in Marcelino Ramos; MCP 19385, 2, 86.0-124.6 mm SL, rio Canoas, on Tupitinga-Celso Ramos road, Tupitinga; MCP 19378, 2, 288.4-309.4 mm SL, rio Pelotas at Passo da Pedra Oveira, Esmeralda; MCP 21650, 1, 170.8 mm SL, rio Quaraí-Mirim, on Uruguaiana-Quaraí road; MCP 26972, 2, 43.0-43.7 mm SL, rio Ibirapuitã, under bridge upstream from the Biological Reserve of Ibirapuitã, Alegrete; MCP 27452, 1, 360.5 mm SL, Arroio Lagoão, rio Ibicuí drainage, on Santiago-Manoel de Freitas road; MCP 27481, 1, 144.4 mm SL, rio Itu, tributary to rio Ibicuí, Santiago; UFRGS 8394, 6, 68.8-94.9 mm SL, arroio Piraí, tributary to rio Negro between Bagé and Dom Pedrito, Bagé. Rio Grande do Sul State. Jacuí basin: MCP 30714, 1, 230.7 mm SL, rio Jacuí-Mirim, Carazinho; MZUSP 25026, 2, 215.9-225.4 mm SL, rio Jacuí at Ernestina dam near Passo Fundo. URUGUAY. Artigas. Uruguay basin: MCP 17616, 1, 79.2 mm SL, arroyo Arumbeba, circa of 22 km Southeast of Artigas; UFRGS 8059, 1, 101.3 mm SL, arroyo Mandiyú, tributary to río Uruguay, Artigas. Cerro Largo. Uruguay basin: MCP 9878, 1, 288.6 mm SL; MCP 9880, 1, 301.9 mm SL; MCP 9896, 1, 506.0 mm SL; MCP 9926, 1, 399.7 mm SL, río Negro at Arreria. Tacuarembó. Uruguay basin: MZUSP 52006, 4, 289.6-321.9 mm SL, río Negro, Rincón del Bonete.

Diagnosis. Hoplias lacerdae differs from the other species of $H$. lacerdae group in the number of pores of the laterosensory system along the ventral surface of dentary (68 vs. 4-6 in $H$. brasiliensis and $H$. intermedius, always 5 in $H$. australis and 4 in $H$. curupira). It can be further distinguished from $H$. brasiliensis and $H$. curupira, in the number of scales along lateral line (43-48 vs. 38-43 and 34-39 respectively).

Description. Morphometric data presented in Table 7. Body cylindrical, deeper than wide. Greatest body depth at vertical through fifth scale anterior to dorsal-fin origin in specimens smaller than $70 \mathrm{~mm}$ SL, closer to dorsal-fin origin in larger specimens. Anterior profile of head slightly rounded in lateral view, more angular in specimens smaller than $160 \mathrm{~mm}$ SL. Dorsal profile of head almost straight. Dorsal margin of orbit at horizontal through of dorsal profile of head in specimens smaller than $100 \mathrm{~mm}$ SL but not reaching dorsal profile of head in larger specimens. Dorsal profile of body slightly convex from vertical through first series of scale of body to dorsal-fin origin; straight and posteroventrally inclined along dorsal-fin base; straight and less inclined to slightly concave from vertical through base of last dorsal-fin ray to origin of dorsal most procurrent caudal-fin ray. Latter portion slightly more concave in specimens smaller than $100 \mathrm{~mm}$ SL. Ventral profile of lower jaw distinctly angular in region of mandibular symphysis, straight to slightly inclined from vertical through anterior nostril to posterior margin of lower jaw. Medial margins of contralateral dentaries running in parallel (Fig. 1ac). Ventral profile of body slightly convex to pelvic-fin origin; straight to approximately convex from latter point to anal-fin origin; straight and posterodorsally inclined along anal-fin
Table 7. Morphometric data of Hoplias lacerdae. Standard length in mm; values 1-14 are percents of standard length and values 15-22 are percents of head length. $\mathrm{n}=$ number of examined specimens.

\begin{tabular}{lccccc}
\hline & Holotype & $\mathrm{n}$ & Mean & Range & $\begin{array}{c}\text { Standard } \\
\text { deviation }\end{array}$ \\
\hline Standard length & 750.0 & 93 & - & $28.4-750.0$ & - \\
1. Body depth & - & 88 & 21.4 & $16.8-25.1$ & 1.8 \\
2. Head length & 28.0 & 89 & 31.1 & $27.6-34.9$ & 1.5 \\
3. Pectoral-fin length & - & 89 & 16.9 & $11.6-19.2$ & 1.3 \\
4. Pelvic-fin length & - & 89 & 17.9 & $15.0-20.4$ & 1.3 \\
5. Anal-fin length & - & 89 & 17.3 & $13.2-19.7$ & 1.2 \\
6. Dorsal-fin length & - & 89 & 26.2 & $23.1-30.6$ & 1.6 \\
7. Dorsal-fin base & 13.9 & 89 & 15.5 & $13.6-18.0$ & 0.9 \\
8. Anal-fin base & 6.2 & 89 & 9.1 & $6.2-11.3$ & 0.8 \\
9. Pre-pectoral distance & - & 88 & 28.5 & $24.6-34.4$ & 1.7 \\
10. Pre-pelvic distance & 56.7 & 88 & 56.0 & $50.6-60.8$ & 2.1 \\
11. Pre-dorsal distance & 50.0 & 88 & 51.3 & $47.6-56.9$ & 2.0 \\
12. Pre-anal distance & 82.0 & 88 & 81.4 & $75.1-87.6$ & 2.6 \\
13. Caudal-peduncle depth & 11.0 & 88 & 13.1 & $10.8-15.1$ & 0.7 \\
14. Caudal-peduncle length & 12.0 & 88 & 13.6 & $11.0-16.4$ & 1.0 \\
15. Head depth & 45.1 & 90 & 41.7 & $37.8-47.1$ & 2.0 \\
16. Snout length & 26.3 & 90 & 25.1 & $22.5-29.0$ & 1.1 \\
17. Snout width & - & 90 & 18.9 & $13.6-22.9$ & 1.3 \\
18. Snout depth & - & 89 & 19.1 & $16.2-21.8$ & 1.3 \\
19. Pre-nasal distance & - & 90 & 15.0 & $11.4-19.1$ & 1.2 \\
20. Orbital diameter & 8.0 & 90 & 18.5 & $8.0-27.8$ & 3.7 \\
21. Interorbital width & 31.0 & 90 & 21.1 & $15.6-30.1$ & 2.9 \\
22. Upper jaw length & 51.4 & 90 & 47.7 & $44.9-51.8$ & 1.5 \\
\hline & & & & &
\end{tabular}

base; straight to slightly concave from last anal-fin ray to anterior most ventral procurrent caudal-fin ray.

Upper jaw slightly shorter than lower jaw, more so in larger specimens ( $c a .380 \mathrm{~mm} \mathrm{SL}$ ). Posterior portion of maxilla dorsally enlarged and extending medially to anterior margins of second and third infraorbitals. Upper and lower lips fleshy with short skin projections covering canines externally. Anterior nostril tubular with anterior slit along its distal half. Anterior and posterior nostrils situated along horizontal through center of orbit, anterior nostril located at approximate one orbital diameter from anterior margin of orbit; posterior nostril midway between anterior nostril and anterior margin of orbit. Eye proportionately larger in smaller specimens. Infraorbital bones well developed and horizontally elongate. Preopercle bearing inumerous laterosensory system pores and partially covered by posterior margin of infraorbitals 3 , 4 , and posteroventral portion of infraorbital 5 . Anteroventral margin of infraorbital 3 relatively straight and posteroventral margin convex. Posterior margin of infraorbital 4 relatively straight and margins of infraorbitals 5 and 6 slightly convex. Small specimens (ca. $70 \mathrm{~mm} \mathrm{SL}$ ) with infraorbital 3 barely reaching orbital rim and proximal ends of infraorbitals 2 and 4 in contact. Larger specimens (ca. $160 \mathrm{~mm} \mathrm{SL}$ ) with infraorbital 4 barely reaching orbital rim and proximal ends of infraorbitals 2 and 5 almost in contact. Specimens larger than $380 \mathrm{~mm} \mathrm{SL}$ with infraorbital 5 progressively separated from rim. Proximal ends of infraorbitals 2 and 6 almost meeting in some of largest specimens examined (ca. $750 \mathrm{~mm} \mathrm{SL}$ ).

Teeth in both jaws conical or canine. Premaxillary teeth in single row. First premaxillary tooth large canine, and fifth 
tooth medium sized. Sixth tooth canine and almost as large as anterior most premaxillary canine. Second to fourth, seventh and eighth premaxillary teeth small. Maxilla with single row of approximately 38 relatively small teeth, except for very well developed canine-like fourth tooth. Dentary with anterior external row of teeth and posterior internal row. External series with three anterior small teeth, followed by two well developed canines, with posterior canine larger than anterior canine and then ten conical teeth, slightly smaller than anterior most dentary canine. Internal series beginning at level of last conical tooth of external row and composed of approximately 15 very small teeth. Accessory ectopterygoid and ectopterygoid toothed. Ectopterygoid with series of small conical teeth along its ventrolateral margin and many smaller viliform teeth medially on its ventral surface. Endopterygoid edentulous.

Distal margins of all fins rounded. Total dorsal-fin rays 12-15 ( $\mathrm{n}=90$; ii,10-13; mode: ii,11, $\mathrm{n}=66$ ). Dorsal fin located at midbody, its origin at vertical through approximately fourth scale anterior on series along pelvic-fin origin. Longest dorsalfin ray approximately three-quarters of body depth in specimens smaller than $160 \mathrm{~mm}$ SL and almost half of body depth in larger specimens. Anal-fin base short. Total analfin rays 9-12 ( $\mathrm{n}=89$; ii,7-10, mode: ii,8, $\mathrm{n}=56)$. Tip of depressed dorsal fin reaching vertical through anal-fin origin in smaller specimens $(<160 \mathrm{~mm} \mathrm{SL})$, but falling short of vertical through that point in larger specimens. Total pectoralfin rays 11-15 ( $=89$; i,10-14; mode: i,12, $n=35)$. Pectoral-fin origin located at vertical through central portion of opercle. Tip of pectoral fin separated from pelvic-fin origin by five to nine scales. Pectoral and pelvic fins of similar size, slightly larger than anal fin in specimens larger than $380 \mathrm{~mm}$ SL. Pelvic-fin rays i,7 $(n=86)$. Pelvic-fin origin situated at midbody approximately four scales posterior to vertical through dorsal-fin origin. Tips of pelvic fin separated from vertical through anal-fin origin by five to seven scales. Caudal-fin rays i,15, $\mathrm{i}(\mathrm{n}=15)$.

Well developed cycloid scales imbricated along body. Dorsal scales begin in series at posterior margin of parietals and overlap supraoccipital spine. Last vertical series of scales on caudal peduncle forms almost straight line on caudal-fin base in specimens smaller than $160 \mathrm{~mm}$ SL, and slightly convex arch on caudal-fin in larger specimens. Anterior margin of scales with small recess and posterior margin rounded. Eight to eleven radii extending from center of scale to its anterior margin and around eighteen radii, some anastomosed, extending from center of scale to its dorsal, posterior and ventral margins. Lateral line straight and complete, extending from posteroventral margin of supracleithrum to posterior most scale in body. Lateral line with 43-48 $(n=89,43$ in one specimen; mode: $46, n=28$ ) perforated scales (Table 2 ). Lateral-line scales with single laterosensory canal. Longitudinal series of scales between lateral line and dorsal-fin origin 4.5-6.5 ( $\mathrm{n}=88$; mode: $5.5, n=61$ ). Longitudinal series of scales between lateral line and pelvic-fin origin 4.5-6.5 ( $\mathrm{n}=86$; mode: $4.5, \mathrm{n}=63$ ). Longitudinal series of scales around caudal peduncle 18-22 ( $\mathrm{n}=88$; mode: $20, \mathrm{n}=73$ ).
Approximately 11 gill rakers on first epibranchial, most in form of small denticulated plates. Lower branch of first branchial arch with five to seven more elongate rakers and approximately 12 plate-like rakers $(\mathrm{n}=18)$. Laterosensory canal along ventral surface of dentary with $6-8$ pores $(n=90$; mode: $7, \mathrm{n}=67$ ) (Table 3 ).

Color in alcohol. Ground coloration of head and body dark to light brown, darker dorsally and paler ventrally. Ventral region white to light yellow in most specimens. Single dark midlateral stripe along lateral line stripe more evident in specimens smaller than $100 \mathrm{~mm}$ SL. Midlateral stripe crossed by five to seven dark bars, each three to five scales wide. Diagonal bars in many specimens continuing posteroventrally approximately two or three longitudinal series of scales ventral of lateral line, resulting in chevron-like pattern more conspicuous in specimens smaller than $160 \mathrm{~mm}$ SL. Dorsal portions of bars more evident than ventral region. Ground coloration of dorsal surface of head, infraorbital region and opercular series dark brown, with dark reticulated pattern on dorsal surface of head in some specimens. Lips with alternating dark and light vertical bands in specimens smaller than $160 \mathrm{~mm}$ SL and completely dark in larger specimens. Coloration of infraorbital region similar to dorsal surface of head. Many specimens with one or two dark stripes extending radially and posteriorly from eye across opercular series and third stripe extending posteroventrally from eye across posterior region of maxilla. Ground coloration of opercular series dark brown. Opercular membrane usually lighter than opercle.

All fins light brown (lighter than body) with dark spots on rays and interradial membranes forming pattern of irregular dark stripes. Stripes of dorsal and caudal fins wider than those of anal fin. Stripes less regular in dorsal fin. Ventral surfaces of pectoral and pelvic fins either lighter than or with same pattern as dorsal surface, but with pattern less conspicuous.

Distribution. Known from the type-locality and its vicinity, rio Ribeira de Iguape basin, and from the rio Uruguay basin, including the río Negro in Uruguay (Fig. 3).

Remarks. Hoplias lacerdae has been regarded as having a wide distribution, occurring in the rio Ribeira de Iguape as well as in rivers of the Amazon, Paraná, São Francisco, Uruguay and other basins. Results presented herein, however, demonstrate that specimens found in the rio Ribeira are morphologically different from those of remaining cited basins with the exception of rio Uruguay. The distribution of Hoplias lacerdae is therefore restricted to rio Ribeira de Iguape and rio Uruguay, being in sympatry with Hoplias australis in the latter basin.

Although samples from the rio Ribeira and rio Uruguay did not differ significantly in the meristic and morphometric features examined in the present study, some geographical disparities should be pointed out. Most specimens from the rio Ribeira have 6.5 and 5.5 scales above and below lateral line, respectively, while the majority of specimens from the rio 


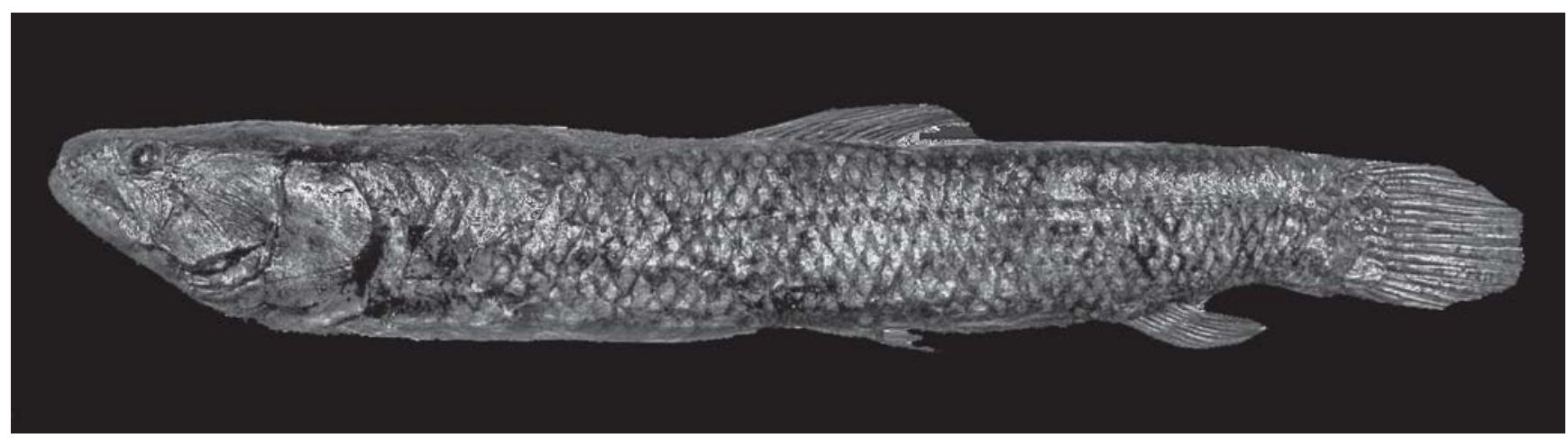

Fig. 11. Hoplias lacerdae, holotype, MNRJ 211, 750.0 mm SL, rio Ribeira de Iguape, São Paulo State, Brazil.

Uruguay have 5.5 and 4.5 scales above and below lateral line respectively. Specimens from the rio Ribeira tend to have fewer lateral line scales than do specimens from the rio Uruguay (modes: 44 and 46, respectively) and more pectoral-fin rays than do samples from the rio Uruguay (i,13-14 vs. i,10-13, respectively). Nevertheless, these subtle differences must be qualified by the fact that they are not absolute and specimens of $H$. lacerdae from the rio Ribeira are rare in collections (only ten specimens were available for this study). More specimens from rio Ribeira and the use of cytogenetics and molecular approaches may determine whether these two populations constitute different species.

Bertolletti et al. (1990) and Pessano et al. (2005) cited $H$. lacerdae from the rio Uruguay basin, the former in the area of Garabi Hydroelectric Station and the latter in Arroio QuaraiChico. These authors, however, did not mention the basis of those identifications, nor did they illustrate their material. Therefore, it is impossible to determine whether they were dealing with Hoplias lacerdae or the new species, H. australis, described herein, both of which occur in the rio Uruguay basin.

A few specimens of Hoplias lacerdae from Ernestina reservoir in the rio Jacuí, a river running into the Atlantic Ocean in Rio Grande do Sul, southern Brazil, were examined. Malabarba (1989: 127) and Carlos Lucena (pers. comm.) mentioned that the species was introduced from rio Uruguay to rio Jacuí system in the 1980s. Native occurrence of Hoplias lacerdae is therefore considered restricted to the rio Uruguay and rio Ribeira de Iguape drainages. Zaniboni Filho et al. (2004) reported some biological features of this species in the rio Uruguay including length, weight, and growth curve. According to them, the species has fractional spawning and an economic importance in local fisheries and aquacultures.

In the rio Ribeira de Iguape, the species is regarded as rare by local fisherman and a two-year survey of its ichthyofauna failed to yield specimens of this species (Oyakawa et al., 2006). The small number of specimens of Hoplias lacerdae from rio Ribeira in ichthyological collections may be additional evidence that this species is uncommon, requiring further studies on its ecology and biology and special attention to its conservation status.

\section{Acknowledgements}

A previous version of this study was part of a dissertation submitted by the senior author in partial fulfillment of a Master's degree in Zoology at the Universidade de São Paulo. This study was developed at the Museu de Zoologia, Universidade de São Paulo, which provided workspace and access to facilities. The authors are deeply grateful to Luiz Malabarba (UFRGS), Patrice Pruvost (MNHN), James Maclaine and Ralf Britz (BMNH) for sending photographs of, and information on, type specimens. Carlos Lucena and Roberto Reis (MCP), Luiz Malabarba (UFRGS), Mark Sabaj Pérez and John Lundberg (ANSP) and David Taphorn (MCNG) greatly contributed to this study by providing information and photographs, lending specimens, and providing access to the collections. Various aspects of this study received valuable input from Mônica Toledo-Piza (IBUSP), José Lima de Figueiredo, Naércio Menezes, Flávio Lima and José Birindelli (MZUSP). Mark Sabaj Pérez (ANSP) and Richard P. Vari (USNM) greatly contributed by kindly reviewing an earlier version of the manuscript. The map of South America is based on one prepared by Marilyn Weitzman. The photograph in Fig. 9 is copyrighted by the Natural History Museum, London. Eduardo Baena took most of remaining pictures and edited Fig. 1. Collecting trips were supported by CNPq - Conselho Nacional de Desenvolvimento Científico e Tecnológico/FINEP Financiadora de Estudos e Projetos/CAPES - Coordenação de Aperfeiçoamento de Pessoal de Nível Superior, Project No. 661058/1997-2, entitled "Conhecimento, Conservação e Utilização Racional da Diversidade da Fauna de Peixes do Brasil” sponsored by Naércio Menezes (MZUSP), and Fundação de Amparo à Pesquisa do Estado de São Paulo (FAPESP) within the BIOTA/FAPESP - The Biodiversity Virtual Institute Program (www.biotasp.org.br), Project No. 00/04300-9, entitled "Diversidade de peixes de riachos e cabeceiras da Bacia do rio Ribeira de Iguape no Estado de São Paulo", sponsored by the senior author. Part of this research was funded by a Böhlke Award (ANSP) to the second author, who also was financially supported by a Doctoral fellowship from CNPq (Project No. 140141/2006-5). 


\section{Literature Cited}

Agostinho, A. A. \& H. F. Júlio Jr. 1999. Peixes da bacia do Alto rio Paraná. Pp. 374-400. In: Lowe-McConnell, R. H. Estudos ecológicos de comunidades de peixes tropicais. São Paulo, EDUSP, 534p.

Alves, C. B. M. \& P. S. Pompeu (Orgs.). 2001. Peixes do rio das Velhas: passado e presente. Belo Horizonte, SEGRAC, 194p.

Alvim, M. C. C. \& A. C. Peret. 2004. Food resources sustaining the fish fauna in a section of the Upper São Francisco River in Três Marias, MG, Brazil. Brazilian Journal of Biology, 64(2): 195-202.

Azevedo, P., J. O. Vaz \& W. B. Parreira. 1965. Redescrição do trairão, Hoplias lacerdae (Ribeiro). Pp. 101-106. In: Anais do II Congresso Latino-Americano de Zoologia, São Paulo, CNPq/ FAPESP, 379p.

Barrella, W. \& M. Petrere Jr. 2003. Fish community alterations due to pollution and damming in Tietê and Paranapanema Rivers (Brazil). River Research and Applications, 19: 59-76.

Bertaco, V.A. \& C. A. S. Lucena. 2006. Two new species of Astyanax (Ostariophysi: Characiformes: Characidae) from eastern Brazil, with a synopsis of the Astyanax scabripinnis species complex. Neotropical Ichthyology, 4(1): 53-60.

Bertolletti, J. J. , C. A. S. Lucena, Z. M. S. Lucena, L. R. Malabarba \& R. E. Reis. 1990. Estrutura e composição da futura usina hidrelétrica de Garabi, Rio Grande do Sul, Brasil. Comunicações do Museu de Ciências da PUCRS, série Zoologia, 3(2): 33-97.

Bertollo, L. A. C., G. G. Born, J. A. Dergam, A. S. Fenocchio \& O. Moreira-Filho. 2000. A biodiversity approach in the neotropical Erythrinidae fish, Hoplias malabaricus. Karyotypic survey, geographical distribution of cytotypes and cytotaxonomic considerations. Chromosome Research, 8: 603-613.

Bertollo, L. A. C., C. S. Takahashi \& O. Moreira-Filho. 1978. Cytotaxonomic considerations on Hoplias lacerdae (Pisces, Erythrinidae). Revista Brasileira de Genética, 1(2): 103-120.

Bertollo, L. A. C., C. S. Takahashi \& O. Moreira-Filho. 1983. Multiple sex chromosomes in the genus Hoplias (Pisces: Erythrinidae). Cytologia, 48: 1-12.

Bizerril, C. R. S. F. 1994. Análise taxonômica e biogeográfica da ictiofauna de água doce do leste brasileiro. Acta Biológica Leopoldensia, 16(1): 51-80.

Bizerril, C. R. S. F. \& N. R. W. Lima. 2000. Levantamento da ictiofauna da bacia do Rio Ribeira, Brasil. Acta Biológica Leopoldensia, 22(1): 103-110.

Britski, H. A. 1972. Peixes de água doce do Estado de São Paulo. Sistemática. Pp. 79-108. In: Poluição e Piscicultura. Faculdade de Saúde Pública e Instituto de Pesca, São Paulo, 216p.

Britski, H. A., Y. Sato \& A. B. S. Rosa. 1984. Manual de identificação de peixes da região de Três Marias: com chaves de identificação para os peixes da Bacia do São Francisco. Brasília, Câmara dos Deputados, Coordenação de Publicações, CODEVASF Divisão de Piscicultura e Pesca, 115p.

Britto, M. R., F. C. T. Lima \& A. C. A. Santos. 2005. A new Aspidoras (Siluriformes: Callichthyidae) from rio Paraguaçu basin, Chapada Diamantina, Bahia, Brazil. Neotropical Ichthyology, 3(4): 473-479.

Castelnau, F. L. L. 1855. Poissons. Pp. 55-56. In: Animaux noveaux ou rares recueillis pendant l'Expedition dans les parties centrales de l'Amerique du Sud, de Rio de Janeiro a Lima, et de Lima au Pará; exécutée par ordre du Gouvernment Français pendant les années 1843 a 1847. Paris, P. Bertrand. v. 2, 112p.

Chomitz, K. M., K. Alger, T. S. Thomas, H. Orlando \& P. V. Nova. 2005. Opportunity costs of conservation in a biodiversity hotspot: the case of southern Bahia. Environment and
Development Economics, 10: 293-312.

Cruz, C. A. G. \& B. V. S. Pimenta. 2004. New species of Physalaemus Fitzinger, 1826 from southern Bahia, Brazil (Anura, Leptodactylidae). Journal of Herpetology, 38(4): 480-486.

Cunico, A. M. \& A. A. Agostinho. 2006. Morphological patterns of fish and their relationships with reservoirs hydrodynamics. Brazilian Archives of Biology and Technology, 49(1): 125-134.

Dergam, J. A. \& L. A. C. Bertollo. 1990. Karyotypic diversification in Hoplias malabaricus (Osteichthyes, Erythrinidae) of the São Francisco and Alto Paraná basins, Brazil. Revista Brasileira de Genética, 13(4): 755-766.

Dergam, J. A., S. R. Paiva, C. E. Schaeffer, A. L. Godinho \& F. Vieira. 2002. Phylogeography and RAPD-PCR variation in Hoplias malabaricus (Bloch, 1794) (Pisces, Teleostei) in southeastern Brazil. Genetics and Molecular Biology, 25(4): 379-387.

Eigenmann, C. H. 1909. The freshwater fishes of Patagonia and an examination of the Archiplata Archelenis Theory. Pp. 225-374. In: Reports on the Princeton University expeditions to Patagônia, 1896-1899, v. 3, pt. 1, 374p.

Eigenmann, C. H. 1910. Catalogue of the freshwater fishes of tropical and South temperate América. Pp. 375-511. In: Reports of the Princeton University expeditions to Patagonia, 1896-1899, v. 3, pt. 2, 777p.

Eigenmann, C. H. 1912. The freshwater fishes of British Guiana, including a study of the ecological grouping of species and relation to the fauna of the plateau to that of the lowlands. Memories of the Carnegie Museum, 5(1): 1-554.

Eigenmann, C. H. \& R. S. Eigenmann. 1889. A review of the Erythrininae. Proceedings of the California Academy of Science, 2(2): 100-117.

Emmons, L. H. \& M. G. Vucetich. 1998. The identity of Winge's Lasiuromys villosus and the description of a new genus of Echimyid rodent (Rodentia: Echimyidae). American Museum Novitates, 3223: 1-12.

Ferraris, Jr. C. J. 2007. Checklist of catfishes, recent and fossil (Osteichthyes: Siluriformes), and catalogue of siluriform primary types. Zootaxa, 1418:1-628.

Fink, W. L. \& S. H. Weitzman. 1974. The so-called cheirodontin fishes of Central America with descriptions of two new species (Pisces: Characidae). Smithsonian Contributions to Zoology, 172: 1-46.

Fowler, H. W. 1950. Os peixes de água doce do Brasil ( $2^{\mathrm{a}}$ entrega). Arquivos de Zoologia, 6: 205-404.

Galindo-Leal, C. \& I. G. Câmara (Eds.). 2005. Mata Atlântica: biodiversidade, ameaças e perspectivas. Belo Horizonte, Fundação SOS Mata Atlântica and Conservation International, 472p.

Garavello, J. C. 2005. Revision of genus Steindachneridion (Siluriformes: Pimelodidae). Neotropical Ichthyology, 3(4): 607-623.

Garutti, V. \& H. A. Britski. 1997. Descrição de uma espécie nova de Astyanax (Teleostei, Characidae), com mancha umeral ovalada horizontalmente, procedente da bacia do Rio Guaporé, Amazônia. Papéis Avulsos de Zoologia, 40(15): 217-229.

Géry, J. 1977. Characoids of the World. New Jersey, T. F. H. Publications, 672p.

Géry, J., V. Mahnert \& C. Dlouhy. 1987. Poissons Characoïdes non Characidae du Paraguay (Pisces, Ostariophysi). Revue Suisse de Zoologie, 94(2): 357-464.

Godoy, M. P. de. 1975. Família Erythrinidae. Pp. 399-444. In: Peixes do Brasil - subordem Characoidei. Bacia do Rio Mogi Guassú. Editora Fransciscana, São Paulo, vol. 3, 399-628 [229p].

Goeldi, E. A. 1898. Primeira contribuição para o conhecimento dos peixes do valle do Amazonas e das Guyanas, estudos ichthyologicos dos annos 1894-1898. Boletim do Museu 
Paraense, 2: 443-488.

Goulding, M. 1980. The fishes and the forest. Explorations in Amazonian Natural History. Los Angeles, University of California Press, 280p.

Günther, A. 1864. Characinidae. Pp. 278-380 In: Catalogue of the fishes in the British Museum. London. V. 5, xxii, 455p.

Harley, R. M. 1988. Evolution and distribution of Eriope (Labiatae), and its relatives, in Brazil. Pp. 71-120. In: Vanzolini, P. E. \& R. H. Heyer (Eds.). Proceedings of a workshop on neotropical distribution patterns. Rio de Janeiro, Academia Brasileira de Ciências, 488p.

ICZN [International Commission on Zoological Nomenclature]. 1999. International Code of Zoological Nomenclature. Fourth Edition. London, International Trust for Zoological Nomenclature, 306p.

Kottelat, M. 1988. Authorship, dates of publication, status and types of Spix and Agassiz's Brazilian fishes. Spixiana, 11(1): 69-93.

Lima, F. C. T., L. Ramos, T. Barreto, A. Cabalzar, G. Tenório, A. Barbosa, F. Tenório \& A. S. Resende. 2005. Peixes do Alto Tiquié - Ictiologia e conhecimentos dos tukuya e tukano. Pp. 111-282. In: Cabalzar, A. (Org.). Peixe e Gente no Alto Rio Tiquié. São Paulo, Instituto Socioambiental, 339p.

Lucinda, P. H. F. 2005. Systematics and biogeography of the genus Phalloptychus Eigenmann, 1907 (Cyprinodontiformes: Poeciliidae: Poeciliinae). Neotropical Ichthyology, 3(3): 373-382.

Lütken, C. F., 2001. Peixes do Rio das Velhas: Uma contribuição para a Ictiologia do Brasil. Pp: 23-164. In: Alves, C. B. M. \& P. S. Pompeu (Org.) Peixes do Rio das Velhas: passado e presente. Belo Horizonte, SEGRAC, 194p.

Malabarba, L. R. 1989. Histórico sistemático e lista comentada das espécies de peixes de água doce do sistema da Laguna dos Patos, Rio Grande do Sul, Brasil. Comunicações do Museu de Ciências da PUCRS, série Zoologia, 2(8): 107-179.

Mattox, G. M. T., M. Toledo-Piza \& O. T. Oyakawa. 2006. Taxonomic study of Hoplias aimara (Valenciennes, 1846) and Hoplias macrophthalmus (Pellegrin, 1907) (Ostariophysi, Characiformes, Erythrinidae). Copeia, 2006(3): 516-528.

Menezes, N. A. 1988. Implications of the distribution patterns of the species of Oligosarcus (Teleostei, Characidae) from central and southern South America. Pp. 295-304. In: Vanzolini, P. E. \& R. H. Heyer (Eds.). Proceedings of a workshop on neotropical distribution patterns. Academia Brasileira de Ciências, Rio de Janeiro, 488p.

Menezes, N. A. 1992. Redefinição taxonômica das espécies de Acestrorhynchus do grupo lacustris com a descrição de uma nova espécie (Osteichthyes, Ostariophysi, Characiformes). Comunicações do Museu de Ciências da PUCRS, série Zoologia, 5: 39-54.

Menezes, N. A., S. H. Weitzman, O. T. Oyakawa, F. C. T. Lima, R. M. C. Castro \& M. J. Weitzman. 2007. Peixes de Água Doce da Mata Atlântica - Lista preliminar das espécies e comentários sobre conservação de peixes de água doce neotropicais. Museu de Zoologia da Universidade de São Paulo, 408p.

Meschiatti, A. J., M. S. Arcifa \& N. Fenerich-Verani. 2000. Fish communities associated with macrophytes in Brazilian floodplain lakes. Environmental Biology of Fishes, 58: 133-143.

Miranda-Ribeiro, A. 1908. Peixes da Ribeira. Resultados de excursão do Sr. Ricardo Krone, membro correspondente do Museu Nacional do Rio de Janeiro. Kosmos, 5: 1-5.

Müller, J. 1842. Beobachtungen über die Schwimmblase der Fische, mit Bezug auf einige neue Fischgattungen. Archives für Anatomie, Physiologie und wissenschaftliche Medicin (J. Müller), 1842: 307-329.
Müller, J. 1843. Beiträge zur Kenntniss der Natürlichen Familien der Fische. Archives für Naturgeschichte, 9(1): 292-330.

Müller, J. \& F. H. Troschel. 1844. Synopsis generum et specierum familiae Characinorum (Prodomus descriptionis novorum generum et specierum). Archives für Naturgeschichte, 10(1): 81-99.

Müller, J. \& F. H. Troschel. 1845. Horae Ichthyologicae, Beschreibung und Abbildung neuer Fische. Die Familie Characinen. Berlin, 40p.

Neumann, D. 2006. Type catalogue of the Ichthyological collection of the Zoologische Staatssammlung München. Part I: Historic type material from the "Old Collection", destroyed in the night 24/25 April 1944. Spixiana, 29(3): 259-285.

Oyakawa, O. T. 1990. Revisão sistemática das espécies do gênero Hoplias (grupo lacerdae) da Amazônia brasileira e região leste do Brasil (Teleostei: Erythrinidae). Unpublished Master Dissertation, Universidade de São Paulo, São Paulo, 114p.

Oyakawa, O. T. 1998. Relações filogenéticas das famílias Pyrrhulinidae, Lebiasinidae e Erythrinidae (Osteichthyes: Characiformes). Unpublished Ph.D. Dissertation, Universidade de São Paulo, São Paulo, 200p.

Oyakawa, O. T. 2003. Family Erythrinidae. Pp. 238-240. In: Reis, R. E., S. O. Kullander \& C. J. Ferraris Jr. (Orgs.). Check list of the freshwater fishes of South and Central America. Porto Alegre, Edipucrs, 729p.

Oyakawa, O. T. \& A. L. Netto-Ferreira. 2007. Família Erythrinidae. Pp. 63-64. In: Buckup, P. A., N. A. Menezes \& M. S. Ghazzi (Orgs.). Catálogo das espécies de peixes de água doce do Brasil. Rio de Janeiro, Museu Nacional, Universidade Federal do Rio de Janeiro, 195p.

Oyakawa, O. T., A. Akama, K. C. Mautari \& J. C. Nolasco. 2006. Peixes de riachos da Mata Atlântica nas Unidades de Conservação do Vale do Rio Ribeira de Iguape no Estado de São Paulo. São Paulo, Editora Neotrópica, 201p.

Pellegrino, K. C. M., M. T. Rodrigues, A. N. Waite, M. Morando, Y. Yonenaga-Yassuda \& J. W. Sites Jr. 2005. Phylogeography and species limits in the Gymnodactylus darwinii complex (Gekkonidae, Squamata): genetic structure coincides with river systems in the Brazilian Atlantic Forest. Biological Journal of the Linnean Society, 85: 13-26.

Penczak, T., L. C. Gomes, L. M. Bini \& A. A. Agostinho. 1998. The importance of qualitative inventory sampling using electric fishing and nets in a large, tropical river (Brazil). Hydrobiologia, 389: 89-100.

Pessano, E. F. C., C. L. O. Azevedo, M. V. M. Querol, E. Querol, L. G. Brasil, L. R. B. Castro, T. B. Pinto \& F. V. Corrêa. 2005. Ictiofauna do arroio Quarai-Chico, bacia do médio Rio Uruguai, no interior do Parque Estadual do Espinilho, Rio Grande do Sul, Brasil. Biotemas, 18(2): 143-153.

Planquette, P., P. Keith \& P.-Y. Le Bail. 1996. Atlas des poissons d'eau douce de Guyane. Tome I. Paris, Muséum Nationale d'Histoire Naturelle, 429p.

Pompeu, P. S. \& C. B. M. Alves. 2003. Local fish extinction in a small tropical lake in Brazil. Neotropical Ichthyology, 1(2): 133-135.

Potter, P. E. 1997. The Mesozoic and Cenozoic paleodrainage of South America: a natural history. Journal of South American Earth Sciences, 10(5-6): 331-344.

Ribeiro, A. C. 2006. Tectonic history and the biogeography of the freshwater fishes from the coastal drainages of eastern Brazil: an example of faunal evolution associated with a divergent continental margin. Neotropical Ichthyology, 4(2): 225-246.

Roberts, T. 1969. Osteology and relationships of characoid fishes, particularly the genera Hepsetus, Salminus, Hoplias, 
Ctenolucius, and Acestrorhynchus. Proceedings of the California Academy of Sciences, 35(15): 391-500.

Rocha, C. F. D, M. van Sluys, H. G. Bergallo \& M. A. S. Alves. 2005. Endemic and threatened tetrapods in the restingas of the biodiversity corridors of Serra do Mar and of the Central da Mata Atlântica in eastern Brazil. Brazilian Journal of Biology, 65(1): 159-168.

Rodrigues, M. T., M. Dixo, D. Pavan \& V. K. Verdade. 2002. A new species of Leposoma (Squamata, Gymnophthalmidae) from the remnant Atlantic forests of the state of Bahia, Brazil. Papéis Avulsos de Zoologia, 42(14): 335-350.

Sarmento-Soares, L. M., R. F. Martins-Pinheiro, A. T. Aranda \& C. C. Chamon. 2006a. Microglanis pataxo, a new catfish from southern Bahia coastal rivers, northeastern Brazil (Siluriformes: Pseudopimelodidae). Neotropical Ichthyology, 4(2): 157-166.

Sarmento-Soares, L. M., R. F. Martins-Pinheiro, A. T. Aranda \& C. C. Chamon. 2006b. Ituglanis cahyensis, a new catfish from Bahia, Brazil (Siluriformes: Trichomycteridae). Neotropical Ichthyology, 4(3): 309-318.

Sato, Y. \& H. P. Godinho. 1999. Peixes da bacia do Rio São Francisco. Pp. 401-413. In: Lowe-McConnell, R. H. (Ed.). Estudos ecológicos de comunidades de peixes tropicais. São Paulo, EDUSP, 534p.

Silva, A. R. M., G. B. Santos \& T. Ratton. 2006a. Fish community structure of Juramento reservoir, São Francisco River basin, Minas Gerais, Brazil. Revista Brasileira de Zoologia, 23(3): 832-840.

Silva, F. S. D., J. R. M. Deus \& A. W. S. Hilsdorf. 2006b. The upper reaches ichthyofauna of the Tietê River, São Paulo, Brazil: aspects of their diversity and conservation. Biodiversity and Conservation, 15: 3569-3577.

Silva, J. M. C., M. C. Sousa \& C. H. M. Castelletti. 2004. Areas of endemism of passerine birds in the Atlantic forest, South America. Global Ecology and Biogeography, 13: 85-92.

Silveira, L. F., P. F. Develey, J. F. Pacheco \& B. M. Whitney. 2005. Avifauna of the Serra das Lontras-Javi montante complex, Bahia, Brazil. Cotinga, 24: 45-54.

Soderstrom, T. R., E. J. Judziewicz \& L. G. Clark. 1988. Distribution patterns of neotropical bamboos. Pp. 121-157. In: Vanzolini, P. E. \& R. H. Heyer (Eds.). Proceedings of a workshop on neotropical distribution patterns. Rio de Janeiro, Academia Brasileira de Ciências, 488p.

Spix, J. B. von \& L. Agassiz. 1829. Selecta genera et species Piscium quos in itinere per Brazilian annis 1817-1820; Peracto et pigendus curavit Dr. J.B. de Spix. Digessit descripsit et observationibus anatomicis illustravit Dr. L. Agassiz. [Memoriae J.B. de Spix] Munich: Typis C. Wolf. xvi, 1-6, 438p.

Steindachner, F. 1874. Die Süsswasserfische dês südöstlichen Brasilien (I). Sitzungsberichte der Kaiserliche Akademie der Wissenschaften, Wien, Mathematisch-naturwissenschaftlichen Classe, 69: 1-40.

Taphorn, D. C. 1992. The characiform fishes of the Apure River drainage, Venezuela. Biollania, edición especial, 4. Monografias Científicas del Museo de Ciencias Naturales, UNELLEZ, Guanare, Venezuela, 537p.

Terofal, F. 1983. Die Fischausbeute der Brasilien-Expedition 18171820 von J. B. v. Spix und C. F. Ph. v. Martius. Spixiana, 9 (supplement): 313-317.

Thomas, W. W., A. M. V. Carvalho, A. M. A. Amorim, J. Garrison \& A. L. Arbeláez. 1998. Plant endemism in two forests in southern Bahia, Brazil. Biodiversity and Conservation, 7: 311-322.

Toledo-Piza, M. 1996. Taxonomic redefinition of the species of Acestrorhynchus of the microlepis group with the description of Acestrorhynchus apurensis, a new species from Venezuela
(Ostariophysi: Characiformes: Characidae). American Museum Novitates, 3160: 1-23.

Valenciennes, A. 1846. Le Macrodon aimara. In: Cuvier, G. L. C. F. D. and A. Valenciennes. Histoire Naturelle des Poissons, v. 19: 523-527. P. Bertrand, Paris, 544p.

Vari, R. P. \& A. S. Harold. 2001. Phylogenetic study of the neotropical fish genera Creagrutus Günther and Piabina Reinhardt (Teleostei: Ostariophysi: Characiformes), with a revision of the cis-andean species. Smithsonian Contributions to Zoology, 613, 239p.

Ventura, K., M. J. J. Silva, V. Fagundes, R. Pardini \& Y. YonenagaYassuda. 2004. An undescribed karyotype for Thaptomys $(2 n=50)$ and the mechanism of differentiation from Thaptomys nigrita $(2 \mathrm{n}=52)$ evidenced by FISH and Ag-NORs. Caryologia, 57(1): 89-97.

Vieira, F., G. B. Santos \& B. M. Alves. 2005. A ictiofauna do Parque Nacional da Serra do Cipó (Minas Gerais, Brasil) e áreas adjacentes. Lundiana, 6 (supplement): 77-87.

Weitzman, S. H. 1962. The osteology of Brycon meeki, a generalized characid fish, with an osteological definition of the family. Stanford Ichthyological Bulletin, 8(1): 1-75.

Weitzman, S. H., N. A. Menezes \& M. J. Weitzman. 1988. Phylogenetic biogeography of the Glandulocaudini (Teleostei: Characiformes: Characidae) with comments on the distribution of other freshwater fishes in eastern and southeastern Brazil. Pp. 379-427. In: Vanzolini, P. E. \& R. H. Heyer, (Eds.). Proceedings of a workshop on neotropical distribution patterns. Rio de Janeiro, Academia Brasileira de Ciências, 488p.

Zanata, A. M. \& A. Akama. 2004. Myxiops aphos, new characid genus and species (Characiformes: Characidae) from the rio Lençóis, Bahia, Brazil. Neotropical Ichthyology, 2(2): 45-54.

Zanata, A. M. \& P. Camelier. 2009. Astyanax vermilion and Astyanax bugerai: new characid fishes (Ostariophysi: Characiformes) from Northeastern Bahia, Brazil. Neotropical Ichthyology, 7(2): 175-184.

Zaniboni Filho, E., S. Meurer, O. A. Shibatta \& A. P. O. Nuñer. 2004. Catálogo ilustrado de peixes do Alto Rio Uruguai. Florianópolis. Editora UFSC, Tractebel Energia, 128p.

Accepted April 2009

Published June 17, 2009 